\title{
Genome-wide analysis of the mouse lung transcriptome reveals novel molecular gene interaction networks and cell-specific expression signatures
}

Rudi Alberts ${ }^{1}$, Lu Lu ${ }^{2,3}$, Robert W Williams ${ }^{2}$ and Klaus Schughart ${ }^{1 *}$

\begin{abstract}
Background: The lung is critical in surveillance and initial defense against pathogens. In humans, as in mice, individual genetic differences strongly modulate pulmonary responses to infectious agents, severity of lung disease, and potential allergic reactions. In a first step towards understanding genetic predisposition and pulmonary molecular networks that underlie individual differences in disease vulnerability, we performed a global analysis of normative lung gene expression levels in inbred mouse strains and a large family of BXD strains that are widely used for systems genetics. Our goal is to provide a key community resource on the genetics of the normative lung transcriptome that can serve as a foundation for experimental analysis and allow predicting genetic predisposition and response to pathogens, allergens, and xenobiotics.
\end{abstract}

Methods: Steady-state polyA+ mRNA levels were assayed across a diverse and fully genotyped panel of 57 isogenic strains using the Affymetrix M430 2.0 array. Correlations of expression levels between genes were determined. Global expression QTL (eQTL) analysis and network covariance analysis was performed using tools and resources in GeneNetwork http://www.genenetwork.org.

Results: Expression values were highly variable across strains and in many cases exhibited a high heri-tability factor. Several genes which showed a restricted expression to lung tissue were identified. Using correlations between gene expression values across all strains, we defined and extended memberships of several important molecular networks in the lung. Furthermore, we were able to extract signatures of immune cell subpopulations and characterize co-variation and shared genetic modulation. Known QTL regions for respiratory infection susceptibility were investigated and several cis-eQTL genes were identified. Numerous cis- and trans-regulated transcripts and chromosomal intervals with strong regulatory activity were mapped. The Cyp1a1 P450 transcript had a strong trans-acting eQTL (LOD 11.8) on Chr 12 at $36 \pm 1 \mathrm{Mb}$. This interval contains the transcription factor Ahr that has a critical mis-sense allele in the DBA/2J haplotype and evidently modulates transcriptional activation by AhR.

Conclusions: Large-scale gene expression analyses in genetic reference populations revealed lung-specific and immune-cell gene expression profiles and suggested specific gene regulatory interactions.

\footnotetext{
* Correspondence: klaus.schughart@helmholtz-hzi.de

'Department of Infection Genetics, Helmholtz Centre for Infection Research

\& University of Veterinary Medicine Hannover, Inhoffenstr. 7, D-38124

Braunschweig, Germany

Full list of author information is available at the end of the article
} 


\section{Background}

The lung is the first line of defense against many pathogens and inhaled xenobiotics and is therefore a key part of the immune system. Host defense is strongly influenced by genetic differences and several studies have shown that the genetic background and sequence difference among humans and other host species modulate susceptibility and resistance to infectious diseases, allergens, and xenobiotics. Systems genetics is a modern extension of complex trait analysis that jointly analyzes and integrates large sets of genotypes and phenotypes to explain and predict variation in outcome measures and disease severity (for review see [1,2]). A typical systems genetics study relies on extensive single nucleotide polymorphism (SNP) data sets, matched data on RNA expression in key cells, tissues, or organs and a core set of key dependent measures such as disease susceptibility [3]. These data are collected across a panel or population of genetically diverse individuals or strains. This group of individuals represents a natural genetic perturbation, with well defined genotype and haplotype differences comprising the "treatment." The independent measurements in this case can consist either of the genotype or of crucial intervening variables such as the expression of genes and proteins.

In this study, we exploited a very well characterized panel of inbred strains of mice (a mouse genetic reference panel) that consists of two parts-a small set of standard inbred strains and a larger family of BXD type recombinant inbred strains. The genome of each $\mathrm{BXD}$ strain represents a mixture of the C57BL/6J and DBA/2J parental background and is homozygous at almost every genomic location. The genomic make-up of each BXD line has been determined by extensive mapping with molecular markers. After performing microarray expression analysis for each of the BXD mice, the expression level of each gene can be used as a quantitative trait ( $e$. g. [4-6]). By comparing these expression values for all BXD mice with their molecular markers data along the genome, genomic expression quantitative trait loci (eQTL) can be identified that are likely to regulate the expression of one or several genes [2,5,7-12]. When an eQTL is located at the same genomic position as the gene itself (within a $10 \mathrm{Mb}$ interval of the gene) it is considered as a cis-eQTL. In this case, variations in the promoter sequence or in elements that determine the stability of the mRNA of the gene are the most likely causes for the observed differences in expression levels. If the eQTL is at a distant location from the regulated gene, the eQTL is referred to as a trans-eQTL.

Here, we performed a global gene expression analysis from the lungs of $47 \mathrm{BXD}$ and eight widely used inbred strains. The aim of our study was to reveal genes and gene networks in mouse lung in steady state condition.
We found that many genes had high variation in expression and that often this variation was highly heritable. This allowed us to identify many cis- and trans-eQTLs. In addition, we used the correlation structure in the data to obtain expression signatures for specific cell types within the lung.

\section{Methods}

\section{Mouse strains and sample preparation}

C57BL/6J, BALB/cByJ, FVB/NJ, and WSB/EiJ, as well as B6D2F1 and D2B6F1 lines were obtained from the University of Tennessee Health Science Center (UTHSC). DBA/2J, 129X1/SvJ, LP/J and SJL/J were obtained from The Jackson Laboratory. Mice from 38 BXD recombinant inbred strains were obtained from UTHSC and mice from nine BXD strains were obtained from The Jackson Laboratory. All animals were housed at UTHSC before sacrifice. Mice were killed by cervical dislocation and whole lungs including blood were removed and placed in RNAlater. Total RNA was extracted from the lungs using RNA STAT-60 (Tel-Test Inc.). RNA from two to five animals per strain were pooled and used for gene expression analysis. Animals used in this study were between 49 and 93 days of age. All inbred strains were profiled for both sexes, and for a given BXD strain either males or females were used. Mice were maintained under specific pathogen free conditions. All protocols involving mice were approved by the UTHSC Animal Care and Use Committee.

\section{Microarray analysis}

Gene expression profiling was performed using Affymetrix GeneChip Mouse Genome 4302.0 Arrays at UTHSC. Samples were amplified according to the recommended protocols by the manufacturer (Affymetrix, Santa Clara, CA, USA). In all cases, 4-5 $\mu \mathrm{g}$ of each biotinylated cRNA preparation was fragmented and included in a hybridization cocktail containing four biotinylated hybridization controls (BioB, BioC, BioD, and Cre), as recommended by the manufacturer. Samples were hybridized for 16 hours. After hybridization, GeneChips were washed, stained with SAPE, and read using an Affymetrix GeneChip fluidic station and scanner.

\section{Data preprocessing and analysis}

Data analysis was performed using the GeneNetwork web service [13], a large resource with phenotypes and mRNA expression data for several genetic reference populations and multiple organisms. The expression data were preprocessed like all other datasets in GeneNetwork: adding an offset of 1 unit to each signal intensity value to ensure that the logarithm of all values were positive, computing the $\log _{2}$ value, performing a quantile normalization of the $\log _{2}$ values for the total set of 
arrays using the same initial steps used by the RMA transform [14], computing the Z scores for each cell value, multiplying all $Z$ scores by 2 and adding 8 to the value of all $Z$ scores. The advantage of this variant of a $\mathrm{Z}$ transformation is that all values are positive and that 1 unit represents approximately a 2 -fold difference in expression as determined using the spike-in control probe sets (see [8] for details). For correlation analyses we used Pearson's correlation unless otherwise stated. Heritability was determined using ANOVA with one factor mouse strain, and by dividing the mean betweenmouse-strain variance by the sum of the mean betweenmouse strain variance plus the mean within-strain variance.

\section{QTL Mapping and expression analyses}

All probe sets were mapped using standard interval mapping methods at $1 \mathrm{cM}$ intervals $(\sim 2 \mathrm{Mb})$ along all autosomes and the $\mathrm{X}$ chromosome. This procedure generates estimates of linkage between variation in transcript expression levels and chromosomal location. The entire set of values can be used to construct a set of QTL maps for all chromosomes (except Chr Y and the mitochondrial genome) in which position is plotted on the $\mathrm{x}$-axis and the strength of linkage-the likelihood ratio statistic (LRS) or log of the odds ratio (LOD)-is plotted on the y-axis. An LRS of 18 or higher is significant at a genome-wide $\mathrm{p}$ value of $<0.5$. To compute LRS values we exploited the computationally efficient Haley-Knott regression equations [15] and a set of 3796 SNPs and microsatellite markers that we and others have genotyped over the past decade [16,17]. In order to rapidly map all 45,101 probe sets we used our customized QTL Reaper code http://qtlreaper.sourceforge. net/. QTL Reaper performs up to a million permutations of an expression trait to calculate the genomewide empirical $p$ value and the LRS scores associated with each interval or marker. The peak linkage value and position was databased in GeneNetwork and users can rapidly retrieve and view these mapping results for any probe set. Any of the QTL maps can also be rapidly regenerated using the same Haley-Knott methods, again using functions imbedded in GeneNetwork. GeneNetwork also enable a search for epistatic interactions (pair scanning function) and composite interval mapping with control for a single marker.

\section{Data quality control}

We used two simple but effective methods to confirm correct sample identification of all data entered into GeneNetwork. Expression of the Xist transcript (probe set 1427262_at) was used to validate the sex of the sample. Xist is involved in the inactivation of one X chromosome in females [18] and is only expressed at high levels in females. Other genes that show strong sex-specific expression are Eif2s3y, Jarid1d and Ddx3y. In addition, we investigated several genes that exhibit a strongly bimodal Mendelian expression pattern, meaning that one parental allele exhibits a high expression level whereas the other allele exhibits a low expression and only the F1 hybrids are intermediate. The expression level of such transcripts is directly correlated with the genotype at this locus and they can collectively be used to confirm sample genotype and hence strain. For example, expression of the Rpgrip1 transcript (probe set 1421144_at) has a distinctly bimodal distribution, intermediate values for $\mathrm{F} 1$ animals, and is associated with a LOD score peak of 50 that corresponds precisely to the location of the cognate gene on $\mathrm{Chr} 14$ at $52.5 \mathrm{Mb}$.

\section{Results}

\section{Variation in gene expression}

The Affymetrix M430 2.0 array that we used includes 45,101 probe sets and provides consensus estimates of expression for the vast majority of all protein coding genes. Table 1 gives an overview of the range of variation across strains in each of the probe sets used. Strikingly, more than 2,000 genes showed a range of expression that was larger than four-fold different between the strain with the lowest and the highest expression. Among the genes with the most extreme range in expression levels were Krt4 (keratin 4), Krt13 (keratin 13) and Krtdap (keratinocyte differentiation associated protein). Another gene with highly variable expression was Cftr (cystic fibrosis transmembrane conductance regulator homolog). This important lung disease-causing gene showed a four-fold variation in expression levels between strains. Several other genes with high variation were sex-specifically expressed genes, like Xist (inactive X specific transcripts), $D d x 3 y$ (DEAD (Asp-Glu-Ala-Asp) box polypeptide 3, Y-linked) and Serpina1b (serine (or cysteine) preptidase inhibitor, clade A, member 1B).

\section{Table 1 Variation in gene expression for 45,101 probe} sets.

\begin{tabular}{ccr}
\hline Fold change range & Log $_{\mathbf{2}}$ range & No. of genes \\
\hline $1-2$ & $0-1$ & 30,392 \\
$2-4$ & $1-2$ & 11,965 \\
$4-8$ & $2-3$ & 1,980 \\
$8-16$ & $3-4$ & 498 \\
$16-32$ & $4-5$ & 132 \\
$32-64$ & $5-6$ & 60 \\
64-inf & 6-inf & 42 \\
\hline
\end{tabular}

Fold changes between the lowest and highest expressed mouse stains per probe sets were cal-culated and divided in seven bins. The corresponding range on $\log _{2}$ scale and the amount of genes in each range are given. 


\section{Heritability of variation in gene expression}

To investigate to which extent the variation in expression was due to genetic effects, we calculated the heritability for each of the genes, which is the fraction of variation in expression caused by genetics. The heritability values ranged from as high as 0.96 (most of the variance was associated with between-strain differences) until as low as 0.01 . Genes with the largest heritability were $C d k 17 /$ Pctk2 (cyclin-dependent kinase 17, probe set 1446130_at), Gm1337 (predicted gene 1337, 1443287_at) and Pdxdc1/KIAA0251 (pyridoxal-dependent decarboxylase domain containing 1, 1452705_at), all having a value above 0.99 . High heritability values indicate that it is likely to successfully map QTLs that influence gene expression values.

\section{Lung-specific genes}

The large dataset in GeneNetwork and its built-in features allowed us to compare the gene ex-pression patterns in the lung with data from 25 other tissues. First, we identified the most highly expressed genes in lung (Table 2 lists the 15 highest expression signals). Two of these genes were highly restricted to the lung and trachea: Sftpc (surfactant associated protein C) and Ager (advanced glycosylation end product-specific receptor) (Figure 1A, B) whereas Scgb1a1 (secretoglobin, family $1 \mathrm{~A}$, member 1 (uteroglobin)) was highly expressed in lung but also showed expression in some other tissues (Figure 1C). On the other hand, Hba-al (hemoglobin alpha, adult chain 1) was expressed at high levels in most tissues (Figure 1D). We then used Stfpc in a tissue
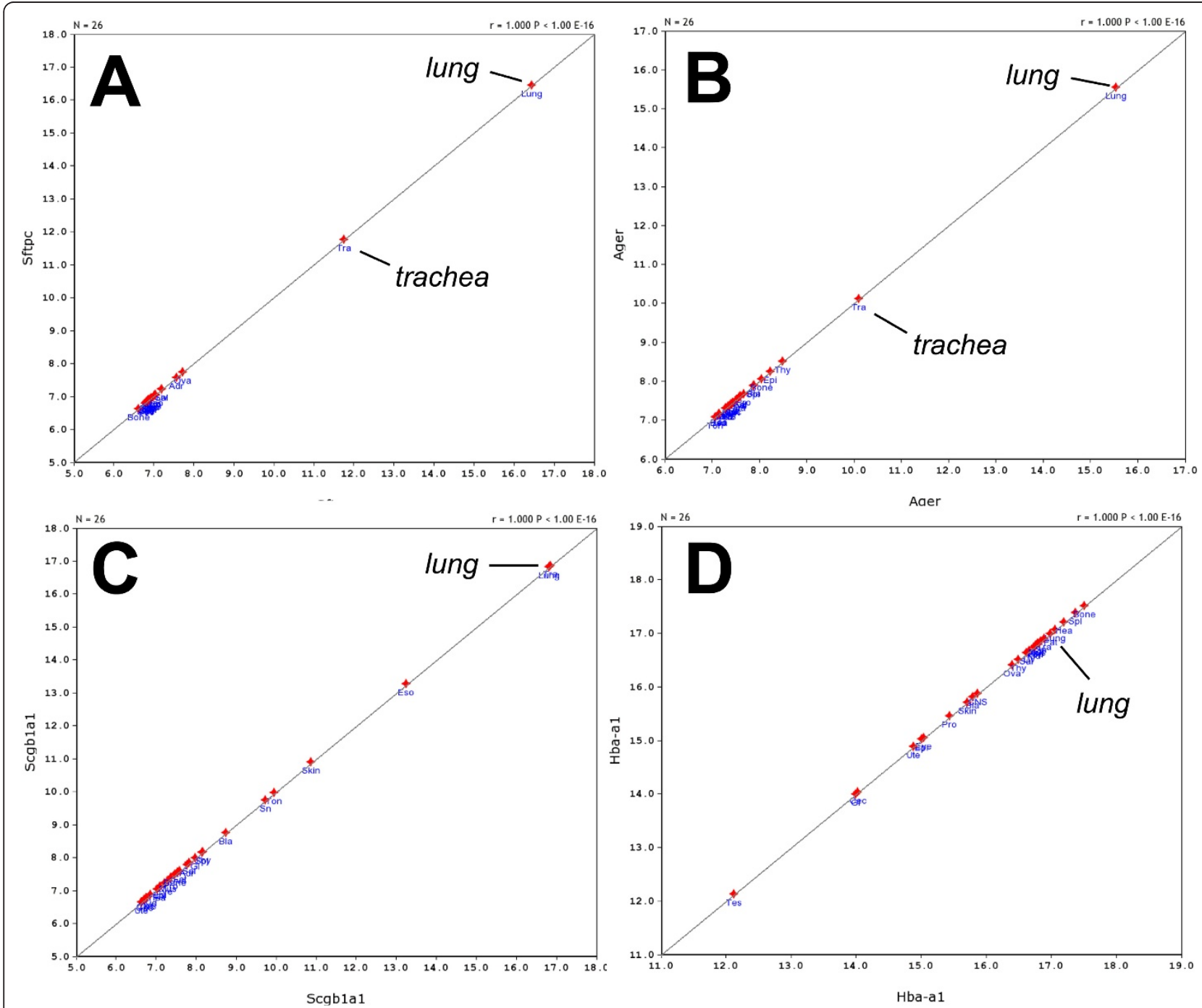

Figure $\mathbf{1}$ Tissue distribution in $\mathbf{2 5}$ other tissues of some of the most highly expressed genes in the lung. The expression levels for (A) Stpc, (B) Ager, (C) Scgblal and (D) Hba-al in different tissues are shown. Please note that in this representation the gene is correlated with itself to illustrate only its issue distribution. 
Table 2 List of 15 probe sets with highest expression signals in the lung

\begin{tabular}{|c|c|c|c|c|c|}
\hline Probe set & Symbol & Description & $\begin{array}{l}\text { Location } \\
\text { (Chr, Mb) }\end{array}$ & $\begin{array}{l}\text { Mean } \\
\text { Expr }\end{array}$ & $\begin{array}{c}\text { Tissue-specific } \\
\text { expression }\end{array}$ \\
\hline 1428361_x_at & Hba-al & hemoglobin alpha, adult chain 1 & $\begin{array}{l}\text { Chr11: } \\
32.184441\end{array}$ & 15,10 & MT \\
\hline 1418639_at & Sftpc & surfactant associated protein $C$ & $\begin{array}{l}\text { Chr14: } \\
70.920826\end{array}$ & 14,92 & LS \\
\hline 1452543_a_at & Scgblal & secretoglobin, family $1 \mathrm{~A}$, member 1 (uteroglobin) & $\begin{array}{l}\text { Chr19: } \\
9.158206\end{array}$ & 14,78 & LHOT \\
\hline 1417184_s_at & $\mathrm{H} b \mathrm{~b}-\mathrm{b} 2$ & hemoglobin, beta adult minor chain & $\begin{array}{l}\text { Chr7: } \\
110.976103\end{array}$ & 14,74 & MT \\
\hline 1441958_s_at & Ager & advanced glycosylation end product-specific receptor & $\begin{array}{l}\text { Chr17: } \\
34.737745\end{array}$ & 14,69 & LS \\
\hline $\begin{array}{l}\text { AFFX-b- } \\
\text { ActinMur/ } \\
\text { M12481 } \\
\text { _3_at }\end{array}$ & Actb & actin beta, cytoplasmic & $\begin{array}{l}\text { Chr5: } \\
143.665528\end{array}$ & 14,67 & MT \\
\hline 1452757_s_at & Hba-al & hemoglobin alpha, adult chain 1 & $\begin{array}{l}\text { Chr11: } \\
32.196742\end{array}$ & 14,66 & MT \\
\hline 1416642_a_at & Tpt1 & tumor protein, translationally-controlled 1 & $\begin{array}{l}\text { Chr14: } \\
76.246098\end{array}$ & 14,62 & MT \\
\hline 1418509_at & Cbr2 & carbonyl reductase 2 & $\begin{array}{l}\text { Chr11: } \\
120.628111\end{array}$ & 14,62 & LHOT \\
\hline 1436996_x_at & Lzp-s & P lysozyme structural and lysozyme & $\begin{array}{l}\text { Chr10: } \\
116.724902\end{array}$ & 14,62 & ND \\
\hline 1416624_a_at & Uba52 & ubiquitin A-52 residue ribosomal protein fusion product 1 & $\begin{array}{l}\text { Chr8: } \\
73.032191\end{array}$ & 14,58 & MT \\
\hline 1427021_s_at & Fth1 & ferritin heavy chain 1 & $\begin{array}{l}\text { Chr19: } \\
\text { 10.057382 }\end{array}$ & 14,57 & ND \\
\hline $\begin{array}{l}\text { AFFX- } \\
\text { MURINE_B2_at }\end{array}$ & B2 & $\begin{array}{l}\text { AFFX-MURINE_B2_at short interspersed nuclear element (SINE) class of repeat } \\
\text { (probes target Chr } 1 \text { and Chr } 2 \text { most heavily) }\end{array}$ & N/A & 14,52 & ND \\
\hline 1415906_at & $\operatorname{Tmsb4x}$ & thymosin, beta $4, X$ chromosome & $\begin{array}{l}\text { ChrX: } \\
163.645132\end{array}$ & 14,51 & MT \\
\hline 1449436_s_at & Ubb & ubiquitin B & $\begin{array}{l}\text { Chr11: } \\
62.366564\end{array}$ & 14,50 & MT \\
\hline
\end{tabular}

Mean Expr: mean expression in lung for BXD strains. LS: lung specific expression, LHOT: highly expressed in lung but also in other tissues, MT: expressed in many tissues or mainly in non-lung tissues, ND: no data for other tissues than lung available.

correlation analysis to identify other genes that may not be as highly expressed but still be restricted to lung tissue. The first 70 probe sets found were then analyzed as above for lung-specific expression, and 15 genes were identified (Table 3). A comparison to the expression patterns described in the BioGPS database [19] confirmed that the majority was only expressed in lung, most of them at high level. Two genes were not restricted to the lung according to BioGPS, and five genes were also found at lower levels in one other tissue (Table 3).

\section{Identification of gene networks using correlations}

The large data set for expression values for $\sim 39,000$ transcripts in 57 mouse strains allowed us to calculate correlations between any pair of genes. A Spearman rank correlation analysis identified 12,985 pairs of genes with a correlation value above 0.8 , and 604 pairs showed a correlation value of 0.9 or higher. For example, the expression of Klra3 (killer cell lectin-like receptor subfamilily A, member 3) was strongly correlated with the expression of Gzma (granzyme A) (Figure 2A). Klra3 also appeared to be strongly correlated with Il18rap (interleukin 18 receptor accessory protein, Figure 2B). We then calculated the first principal component of the Klra3, Gzma, Il18rap and Klrg1 (killer cell lectin-like receptor subfamily $G$, member 1 ) genes and used it to determine the correlations with all other genes in the lung data set. In this way, we could identify a network of nine genes exhibiting a correlation of $>=$ 0.8 with this principal component (Figure 2C). One of the newly identified genes was $\operatorname{Prf1}$ (perforin 1) which was correlated with a p-value of $<10^{-16}$ with the principal component (Figure 2D). If genes exhibit a strong correlation of their expression values, one may hypothesize that they are involved in the same biological process or pathway, or they may be expressed in the same cell type.

In a similar way, we identified another gene network of 20 genes that exhibited very high correlations of their 
Table 3 List of genes with lung-restricted expression found by tissue correlation analysis with Sftpc

\begin{tabular}{|c|c|c|c|c|c|}
\hline Probe set & Symbol & Description & $\begin{array}{l}\text { Location } \\
\text { (Chr, Mb) }\end{array}$ & $\begin{array}{l}\text { Mean } \\
\text { Expr }\end{array}$ & BioGPS expression \\
\hline 1418639_at & Sftpc & surfactant associated protein C & $\begin{array}{l}\text { Chr14: } \\
70.920826\end{array}$ & 14,92 & $\begin{array}{l}\text { high in lung, low in nucleus } \\
\text { accumbens }\end{array}$ \\
\hline 1437028_at & Sftpb & $\begin{array}{l}\text { surfactant associated protein B (nonciliated bronchiolar and } \\
\text { alveolar type } 2 \text { cell signature) }\end{array}$ & $\begin{array}{l}\text { Chr6: } \\
72.260763\end{array}$ & 13,68 & high in lung only \\
\hline 1422334_a_at & Sftpal & surfactant associated protein A1 & $\begin{array}{l}\text { Chr14: } \\
\text { 41.946994 }\end{array}$ & 14,24 & high in lung only \\
\hline 1422346_at & $\begin{array}{l}\text { Nkx2-1 } \\
\text { (Titf1) }\end{array}$ & thyroid transcription factor 1 & $\begin{array}{l}\text { Chr12: } \\
57.634187\end{array}$ & 8,07 & lung only \\
\hline 1417057_a_at & Lamp3 & lysosomal-associated membrane protein 3 & $\begin{array}{l}\text { Chr16: } \\
\text { 19.653875 }\end{array}$ & 12,09 & $\begin{array}{l}\text { high in lung, low in ES cells and } \\
\text { some cell lines }\end{array}$ \\
\hline 1421404_at & Cxcl15 & chemokine (C-X-C motif) ligand 15 & $\begin{array}{l}\text { Chr5: } \\
91.230349\end{array}$ & 13,87 & high in lung only \\
\hline 1441958_s_at & Ager & advanced glycosylation end product-specific receptor & $\begin{array}{l}\text { Chr17: } \\
34.737745\end{array}$ & 14,69 & high in lung only \\
\hline 1436787_x_at & $\sec 14 / 3$ & SEC14-like protein 3 & $\begin{array}{l}\text { Chr11: } \\
3.978573\end{array}$ & 13,21 & $\begin{array}{l}\text { only data for human available - } \\
\text { not lung specific }\end{array}$ \\
\hline 1425218_a_at & $\operatorname{scgb3a2}$ & secretoglobin, family $3 \mathrm{~A}$, member 2 & $\begin{array}{l}\text { Chr18: } \\
43.924081\end{array}$ & 14,17 & high in lung only \\
\hline 1449428_at & Cldn18 & claudin 18 & $\begin{array}{l}\text { Chr9: } \\
99.591247\end{array}$ & 12,70 & highest in lung, lower in stomach \\
\hline 1449525_at & Fmo3 & flavin containing monooxygenase 3 & $\begin{array}{l}\text { Chr1: } \\
\text { 164.884088 }\end{array}$ & 10,90 & $\begin{array}{l}\text { high in lung, maybe weak in } \\
\text { some other tissues }\end{array}$ \\
\hline 1425814_a_at & Calcrl & calcitonin receptor-like & $\begin{array}{l}\text { Chr2: } \\
84.170818\end{array}$ & 12,91 & $\begin{array}{l}\text { high in lung, weak in } \\
\text { macrophages }\end{array}$ \\
\hline 1421373_at & Cox4i2 & cytochrome c oxidase subunit IV isoform 2 & $\begin{array}{l}\text { Chr2: } \\
152.582819\end{array}$ & 9,24 & not specific for lung \\
\hline 1419699_at & Scgb3al & secretoglobin, family $3 \mathrm{~A}$, member 1 & $\begin{array}{l}\text { Chr11: } \\
49.477871\end{array}$ & 13,68 & high in lung only \\
\hline 1451604_a_at & Acvrll & activin A receptor, type II-like 1 & $\begin{array}{l}\text { Chr15: } \\
\text { 100.968668 }\end{array}$ & 11,86 & high in lung only \\
\hline 1420347_at & Plunc & palate, lung, and nasal epithelium carcinoma associated & $\begin{array}{l}\text { Chr2: } \\
\text { 153.973359 }\end{array}$ & 13,42 & high in lung, low in heart \\
\hline
\end{tabular}

Mean Expr: mean expression in lung for BXD strains. BioGPS: evaluation of expression pattern as described in BioGPS.

expression levels across all mouse strains. All possible pairs of genes in this network showed a correlation above 0.95 (Figure 3). The network contained two keratin genes, Krt4 (keratin 4) and Krt13 (keratin 13) and genes involved in cytoskeleton functions, again pointing to a possible interaction of these genes in the same pathway or biological process. Further gene networks found by correlation studies were related to $\mathrm{B}$ and $\mathrm{T}$ cells (see below).

\section{Correlation analysis identified gene expression signatures for $T$ and $B$ cells}

The hemoglobin genes Hba-a1 (hemoglobin alpha, adult chain 1) and $H b b-b 2$ (hemoglobin beta, adult minor chain) were among the top 10 genes with highest expression values in our lung data set. The high levels of hemoglobin transcripts suggested that circulating blood cells, including immune cells, may also be analyzed in our data set. Therefore, we investigated the gene expression networks of known immune cell markers, e.g. Cd3 genes as specific markers for T cells. We calculated the correlations of $C d 3 d$ ( $\mathrm{Cd} 3$ antigen, delta polypeptide) expression levels over all BXD lines with all other genes. This analysis revealed 20 genes with a very highly correlated expression value ( $\mathrm{p}$-value below $10^{-14}$, Figure 4). Most of these genes were known $\mathrm{T}$ cell markers or involved in $\mathrm{T}$ cell regulation. Eight out of the 12 genes with the strongest correlations were also exclusively expressed in $\mathrm{T}$ cells according to the BioGPS database (Wu et al., 2009): Cd3d, Itk, Tcrb-13V Cd3e, Cd3g, Scap1, Cd6 and Cd5 (see Figure 4 for full gene names). Similarly, we searched for B cell-specific signatures starting with the B cell marker gene $C d 19$ (CD19 antigen). The probe set "1450570_a_at" detected Cd19 mRNA levels and showed a mean expression level of 9.3. We found 14 probe sets with a correlation above 0.80 (p-value $<10^{-14}$, Figure 5). A comparison with the BioGPS database revealed that eight of them, $C d 19$, Cd79b, Faim3, Cd79a, Blk, B3gnt5, Cd22 and Blr1 (see Figure 5 for full gene names) were also exclusively 


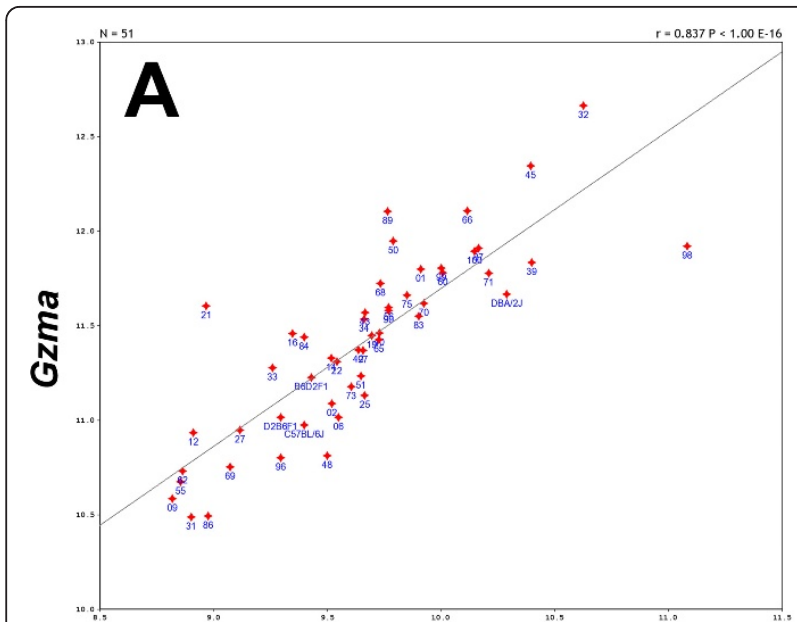

KIra3

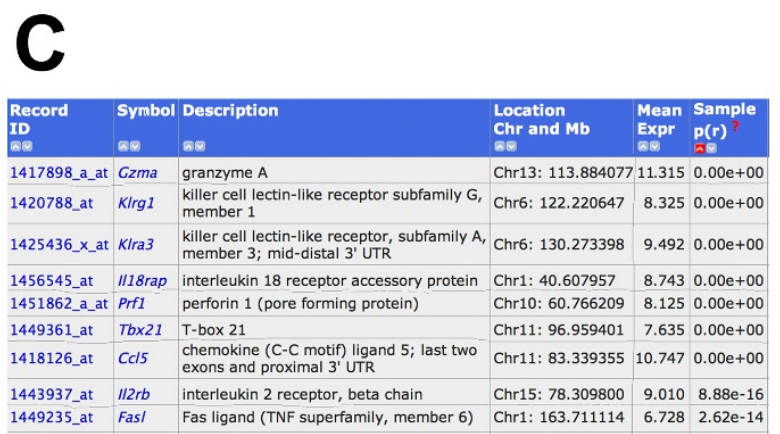

expressed in B cells. Therefore, these genes can be considered as $\mathrm{T}$ and $\mathrm{B}$ cell signature genes which may be used to follow the presence and infiltration of $\mathrm{T}$ and $\mathrm{B}$ cells in the lung under normal and pathological conditions.

\section{Identification of candidate genes regulating phenotypic traits in the lung}

Once a QTL for a phenotypic trait has been found, it will be important to identify the underlying quantitative gene (QTG) which is causing the variation. Searching cis-eQTLs in the QTL interval represents one suitable approach [8]. As a prototype for this approach in our lung data set, we examined two traits for which lung phenotypes were studied in the BXD population and
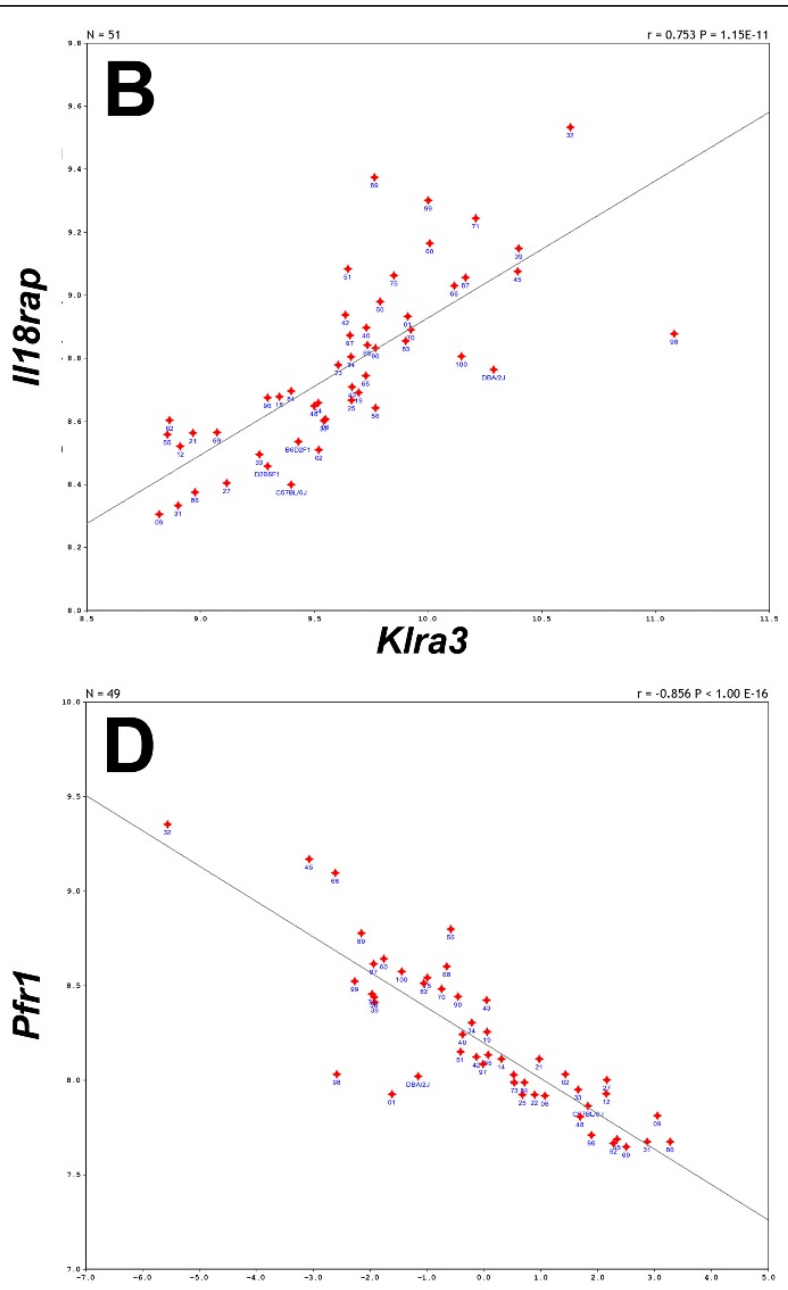

first principal component

Figure 2 Expression signals for strongly correlated genes in the lung. Numbers indicate BXD strains, and the parental C57BL/6J and DBA/2J strains as well as F1 individuals are presented. Expression signals of (A) Klra3 and Gzma $\left(p<10^{-16}\right)$ and (B) KIra3 versus $1 / 18$ rap $\left(p<10^{-11}\right)$ were (D) Strong correlation between the first principal component and $\operatorname{Prfl}\left(\mathrm{p}<10^{-16}\right)$. X-and $Y$-axis of the plots show the names of genes used for the analysis.

which were available in GeneNetwork. Boon et al. [20] described several QTLs for the susceptibility of BXD mice to influenza A infections. We analyzed one significant QTL peak on chromosome 2 and two suggestive peaks on chromosomes 7 and 17. Seven cis-eQTL regulated genes were found in the chromosome 2 QTL interval (Table 4), including the $H c$ (hemolytic complement) gene which was shown to contribute to influenza susceptibility [20]. The analysis of the QTL region on chromosome 7 revealed 12 cis-regulated genes in the lung, including Trim12 (tripartite motif protein 12) and Trim34 (tripartite motif protein 34 ) which were also described as potential candidate QTGs by [20]. In the chromosome 17 QTL region, we found 17 cis-eQTL genes, of which Prkcn (protein kinase C, nu), Qpct 


\begin{tabular}{|c|c|c|c|c|c|c|c|c|c|c|c|c|c|c|c|c|c|c|c|c|}
\hline \multicolumn{21}{|c|}{ Spearman Rank Correlation (rho) } \\
\hline & Trait1 & Trait2 & Trait3 & Trail4 & Trait5 & Trait6 & Trait7 & Trait8 & Trait9 & Trait10 & Trait11 & Trait12 & Trait13 & Trait14 & Trait15 & Trait16 & Trait17 & Trait18 & Trait19 & Trait20 \\
\hline $\begin{array}{l}\text { Trait 1: HZI_0408_R:1422454_at } \\
\text { Symbol: Krt13 }\end{array}$ & $\begin{array}{c}n \\
s_{1}\end{array}$ & $\begin{array}{c}0.976 \\
51\end{array}$ & $\frac{0.969}{51}$ & $\begin{array}{c}0.948 \\
51\end{array}$ & $\underset{51}{0.942}$ & ${ }_{51}^{0.952}$ & $\begin{array}{c}0.962 \\
51\end{array}$ & $\begin{array}{c}0.924 \\
51\end{array}$ & $\begin{array}{c}0.972 \\
51\end{array}$ & $\begin{array}{c}0.953 \\
51\end{array}$ & $\begin{array}{c}0.965 \\
51\end{array}$ & $\begin{array}{c}0.942 \\
51\end{array}$ & $\underset{51}{0.972}$ & $\frac{0.973}{51}$ & $\frac{0.925}{51}$ & $\frac{0.972}{51}$ & $\underset{51}{0.916}$ & $\frac{0.950}{51}$ & 0.964 & $\underset{51}{0.903}$ \\
\hline $\begin{array}{l}\text { Trait 2: HZZ_0408_R:1418735_at } \\
\text { Symbol: Krt4 }\end{array}$ & ${ }_{51}^{0.997}$ & ${ }_{51}^{n}$ & $\begin{array}{l}0.988 \\
51\end{array}$ & $\begin{array}{c}0.942 \\
51\end{array}$ & $\begin{array}{c}0.966 \\
51\end{array}$ & 0.972 & $\begin{array}{c}0.977 \\
51\end{array}$ & $\begin{array}{c}0.911 \\
51\end{array}$ & $\begin{array}{c}0.977 \\
51\end{array}$ & $\begin{array}{c}0.937 \\
51\end{array}$ & $\begin{array}{c}0.946 \\
51\end{array}$ & $\begin{array}{l}0.893 \\
51\end{array}$ & $\begin{array}{c}0.959 \\
51\end{array}$ & $\begin{array}{c}0.984 \\
51\end{array}$ & $\begin{array}{l}0.924 \\
51\end{array}$ & $\begin{array}{c}0.988 \\
51\end{array}$ & $\begin{array}{c}0.945 \\
51\end{array}$ & $\begin{array}{c}0.942 \\
51\end{array}$ & $\begin{array}{l}0.945 \\
51\end{array}$ & $\begin{array}{l}0.868 \\
51\end{array}$ \\
\hline $\begin{array}{l}\text { Trait 3: HZ1_0408_R:1438394___at } \\
\text { Symbol: Krt4 }\end{array}$ & $\begin{array}{l}0.996 \\
51\end{array}$ & $\underset{51}{0.995}$ & $\begin{array}{c}n \\
{ }_{51}\end{array}$ & $\begin{array}{c}0.924 \\
51\end{array}$ & $\begin{array}{c}0.956 \\
51\end{array}$ & $\begin{array}{c}0.984 \\
51\end{array}$ & $\begin{array}{c}0.977 \\
51\end{array}$ & $\begin{array}{c}0.909 \\
51\end{array}$ & 0.969 & $\begin{array}{l}0.944 \\
51\end{array}$ & $\underset{51}{0.942}$ & $\begin{array}{c}0.882 \\
51\end{array}$ & $\frac{0.938}{51}$ & $\frac{0.970}{51}$ & ${ }_{51}^{0.924}$ & 0.978 & $\begin{array}{l}0.943 \\
51\end{array}$ & $\begin{array}{c}0.917 \\
51\end{array}$ & 0.946 & $\begin{array}{c}0.863 \\
51\end{array}$ \\
\hline $\begin{array}{l}\text { Trait 4: HZ1_0408_R:1434227_at } \\
\text { Symbol: Krtdap }\end{array}$ & $\begin{array}{l}0.993 \\
51\end{array}$ & 0.994 & $\begin{array}{l}0.988 \\
51\end{array}$ & $\begin{array}{c}n \\
51\end{array}$ & ${ }_{51}^{0.882}$ & $\frac{0.918}{51}$ & $\begin{array}{c}0.923 \\
51\end{array}$ & 0.942 & $\begin{array}{c}0.929 \\
51\end{array}$ & $\begin{array}{c}0.899 \\
51\end{array}$ & $\begin{array}{c}0.908 \\
51\end{array}$ & $\begin{array}{c}0.908 \\
51\end{array}$ & $\begin{array}{l}0.934 \\
51\end{array}$ & ${ }_{51}^{0.936}$ & $\begin{array}{c}0.838 \\
51\end{array}$ & $\begin{array}{l}0.935 \\
51\end{array}$ & ${ }_{51}^{0.929}$ & 0.972 & 0.916 & $\begin{array}{l}0.902 \\
51\end{array}$ \\
\hline $\begin{array}{l}\text { Trait 5: HZI_0408_R:1448745_s_at } \\
\text { Symbol: Lor }\end{array}$ & ${ }_{51}^{0.990}$ & $\begin{array}{c}0.991 \\
51\end{array}$ & $\begin{array}{l}0.986 \\
51\end{array}$ & $\begin{array}{c}0.987 \\
51\end{array}$ & ${ }_{51}^{n}$ & $\begin{array}{c}0.949 \\
51\end{array}$ & $\begin{array}{c}0.955 \\
51\end{array}$ & $\begin{array}{c}0.854 \\
51\end{array}$ & $\begin{array}{c}0.952 \\
51\end{array}$ & $\begin{array}{c}0.930 \\
51\end{array}$ & $\begin{array}{c}0.938 \\
51\end{array}$ & $\begin{array}{c}0.881 \\
51\end{array}$ & $\begin{array}{c}0.927 \\
51\end{array}$ & $\begin{array}{l}0.966 \\
51\end{array}$ & $\begin{array}{c}0.965 \\
51\end{array}$ & $\begin{array}{c}0.960 \\
51\end{array}$ & $\begin{array}{c}0.925 \\
51\end{array}$ & $\begin{array}{c}0.909 \\
51\end{array}$ & $\begin{array}{c}0.925 \\
51\end{array}$ & $\begin{array}{l}0.824 \\
51\end{array}$ \\
\hline $\begin{array}{l}\text { Trait 6: HZI_0408_R:1456248_at } \\
\text { Symbol: 2310002A05Rik }\end{array}$ & $\begin{array}{l}0.989 \\
51\end{array}$ & $\underset{51}{0.989}$ & $\begin{array}{l}0.987 \\
51\end{array}$ & $\frac{0.985}{51}$ & $\underset{51}{0.983}$ & $\begin{array}{c}n \\
51\end{array}$ & $\begin{array}{c}0.980 \\
51\end{array}$ & $\begin{array}{c}0.919 \\
51\end{array}$ & $\begin{array}{c}0.968 \\
51\end{array}$ & $\begin{array}{c}0.942 \\
51\end{array}$ & $\begin{array}{c}0.934 \\
51\end{array}$ & $\begin{array}{l}0.876 \\
51\end{array}$ & $\frac{0.926}{51}$ & 0.964 & $\frac{0.921}{51}$ & 0.963 & 0.956 & 0.911 & 0.948 & $\begin{array}{l}0.854 \\
51\end{array}$ \\
\hline $\begin{array}{l}\text { Trait 7: HZ1_0408_R:1453092_at } \\
\text { Symbol: 2300002G24Rik }\end{array}$ & $\begin{array}{l}0.985 \\
51\end{array}$ & $\underset{51}{0.985}$ & $\begin{array}{l}0.978 \\
51\end{array}$ & $\begin{array}{c}0.982 \\
51\end{array}$ & $\begin{array}{c}0.981 \\
51\end{array}$ & $\underset{51}{0.993}$ & $\begin{array}{c}n \\
{ }_{51}\end{array}$ & $\begin{array}{c}0.908 \\
51\end{array}$ & $\begin{array}{c}0.972 \\
51\end{array}$ & $\begin{array}{c}0.956 \\
51\end{array}$ & $\begin{array}{c}0.949 \\
51\end{array}$ & $\begin{array}{c}0.907 \\
51\end{array}$ & $\begin{array}{c}0.945 \\
51\end{array}$ & $\begin{array}{c}0.976 \\
51\end{array}$ & $\begin{array}{c}0.935 \\
51\end{array}$ & 0.971 & $\begin{array}{c}0.945 \\
51\end{array}$ & $\frac{0.934}{51}$ & $\begin{array}{l}0.953 \\
51\end{array}$ & $\begin{array}{c}0.872 \\
51\end{array}$ \\
\hline $\begin{array}{l}\text { Trait 8: HZ1_0408_R:1450645_at } \\
\text { Symbol: Mt4 }\end{array}$ & $\begin{array}{l}0.983 \\
51\end{array}$ & $\underset{51}{0.985}$ & $\begin{array}{l}0.981 \\
51\end{array}$ & $\begin{array}{c}0.984 \\
51\end{array}$ & $\begin{array}{c}0.968 \\
51\end{array}$ & $\begin{array}{c}0.986 \\
51\end{array}$ & $\begin{array}{c}0.978 \\
51\end{array}$ & ${ }_{51}^{n}$ & $\begin{array}{c}0.898 \\
51\end{array}$ & $\begin{array}{c}0.894 \\
51\end{array}$ & $\begin{array}{c}0.911 \\
51\end{array}$ & $\begin{array}{c}0.890 \\
51\end{array}$ & $\begin{array}{c}0.890 \\
51\end{array}$ & $\begin{array}{c}0.885 \\
51\end{array}$ & $\begin{array}{l}0.838 \\
51\end{array}$ & $\begin{array}{c}0.899 \\
51\end{array}$ & $\begin{array}{c}0.929 \\
51\end{array}$ & $\begin{array}{l}0.918 \\
51\end{array}$ & $\begin{array}{l}0.934 \\
51\end{array}$ & $\begin{array}{l}0.905 \\
51\end{array}$ \\
\hline $\begin{array}{l}\text { Trait 9: HZI_0408_R:1456001_at } \\
\text { Symbol: 2310007F04Rik }\end{array}$ & 0.982 & $\underset{51}{0.983}$ & 0.976 & $\begin{array}{c}0.979 \\
51\end{array}$ & $\underset{51}{0.975}$ & 0.992 & $\begin{array}{c}0.989 \\
51\end{array}$ & 0.981 & ${ }_{51}^{n}$ & $\begin{array}{c}0.945 \\
51\end{array}$ & $\begin{array}{c}0.950 \\
51\end{array}$ & $\begin{array}{c}0.900 \\
51\end{array}$ & $\begin{array}{l}0.961 \\
51\end{array}$ & $\begin{array}{l}0.978 \\
51\end{array}$ & $\begin{array}{c}0.911 \\
51\end{array}$ & $\begin{array}{l}0.982 \\
51\end{array}$ & $\frac{0.933}{51}$ & $\begin{array}{c}0.936 \\
51\end{array}$ & $\begin{array}{l}0.958 \\
51\end{array}$ & $\begin{array}{l}0.875 \\
51\end{array}$ \\
\hline $\begin{array}{l}\text { Trait 10: HZ1_0408_R:1420431_at } \\
\text { Symbol: Rptn }\end{array}$ & $\begin{array}{l}0.981 \\
51\end{array}$ & 0.979 & $\begin{array}{l}0.976 \\
51\end{array}$ & $\begin{array}{c}0.975 \\
51\end{array}$ & 0.973 & $\begin{array}{c}0.984 \\
51\end{array}$ & $\begin{array}{c}0.987 \\
51\end{array}$ & $\frac{0.974}{51}$ & $\begin{array}{c}0.984 \\
51\end{array}$ & ${ }_{51}^{n}$ & $\begin{array}{c}0.965 \\
51\end{array}$ & $\begin{array}{c}0.955 \\
51\end{array}$ & $\begin{array}{c}0.936 \\
51\end{array}$ & $\begin{array}{l}0.941 \\
51\end{array}$ & $\begin{array}{c}0.939 \\
51\end{array}$ & $\begin{array}{c}0.943 \\
51\end{array}$ & $\begin{array}{c}0.892 \\
51\end{array}$ & $\begin{array}{c}0.913 \\
51\end{array}$ & $\begin{array}{l}0.970 \\
51\end{array}$ & ${ }_{51}^{0.881}$ \\
\hline $\begin{array}{l}\text { Trait 11: HZ1_0408_R:1437344___at } \\
\text { Symbool: Krt13 }\end{array}$ & $\begin{array}{l}0.980 \\
51\end{array}$ & $\begin{array}{l}0.978 \\
51\end{array}$ & $\begin{array}{l}0.973 \\
51\end{array}$ & $\begin{array}{l}0.974 \\
51\end{array}$ & $\begin{array}{c}0.971 \\
51\end{array}$ & $\begin{array}{c}0.986 \\
51\end{array}$ & $\begin{array}{c}0.988 \\
51\end{array}$ & $\begin{array}{c}0.981 \\
51\end{array}$ & 0.990 & $\begin{array}{c}0.991 \\
51\end{array}$ & ${ }_{51}^{n}$ & $\begin{array}{c}0.949 \\
51\end{array}$ & $\begin{array}{c}0.953 \\
51\end{array}$ & $\begin{array}{c}0.939 \\
51\end{array}$ & $\begin{array}{c}0.948 \\
51\end{array}$ & $\begin{array}{c}0.954 \\
51\end{array}$ & $\begin{array}{c}0.890 \\
51\end{array}$ & $\frac{0.933}{51}$ & $\begin{array}{l}0.970 \\
51\end{array}$ & $\begin{array}{c}0.898 \\
51\end{array}$ \\
\hline $\begin{array}{l}\text { Trait 12: HZ1_0408_R:1429297_at } \\
\text { Symbol: Serpinb12 }\end{array}$ & 0.980 & 0.975 & 0.968 & $\begin{array}{c}0.977 \\
51\end{array}$ & 0.973 & 0.974 & 0.982 & 0.968 & 0.975 & $\begin{array}{c}0.990 \\
51\end{array}$ & $\begin{array}{c}0.987 \\
51\end{array}$ & $\begin{array}{l}n \\
51\end{array}$ & $\frac{0.929}{51}$ & $\begin{array}{c}0.909 \\
51\end{array}$ & $\begin{array}{c}0.908 \\
51\end{array}$ & $\begin{array}{c}0.897 \\
51\end{array}$ & $\begin{array}{l}0.855 \\
{ }_{51}\end{array}$ & 0.926 & $\begin{array}{l}0.938 \\
51\end{array}$ & $\begin{array}{c}0.895 \\
51\end{array}$ \\
\hline $\begin{array}{l}\text { Trait 13: HZ1_0408_R:1422401_at } \\
\text { Symbol: Spprr3 }\end{array}$ & $\begin{array}{l}0.979 \\
51\end{array}$ & 0.979 & 0.971 & ${ }_{51}^{0.981}$ & $\frac{0.972}{51}$ & $\begin{array}{c}0.983 \\
51\end{array}$ & $\begin{array}{c}0.986 \\
51\end{array}$ & $\begin{array}{c}0.974 \\
51\end{array}$ & $\begin{array}{l}0.988 \\
51\end{array}$ & $\begin{array}{c}0.982 \\
51\end{array}$ & $\begin{array}{c}0.986 \\
51\end{array}$ & $\frac{0.980}{51}$ & $\begin{array}{l}n \\
51\end{array}$ & ${ }_{51}^{0.974}$ & $\begin{array}{c}0.908 \\
51\end{array}$ & $\begin{array}{c}0.969 \\
51\end{array}$ & $\begin{array}{c}0.887 \\
51\end{array}$ & $\begin{array}{c}0.954 \\
51\end{array}$ & $\begin{array}{l}0.947 \\
51\end{array}$ & $\begin{array}{l}0.901 \\
51\end{array}$ \\
\hline $\begin{array}{l}\text { Trait 14: HZ1_0408_R:1452732_at } \\
\text { Symbol: Asprv1_1 }\end{array}$ & $\frac{0.979}{51}$ & $\begin{array}{l}0.979 \\
51\end{array}$ & $\begin{array}{l}0.971 \\
51\end{array}$ & $\begin{array}{c}0.977 \\
51\end{array}$ & $\begin{array}{c}0.981 \\
51\end{array}$ & $\begin{array}{c}0.988 \\
51\end{array}$ & $\begin{array}{c}0.989 \\
51\end{array}$ & $\underset{51}{0.968}$ & $\begin{array}{c}0.991 \\
51\end{array}$ & $\begin{array}{l}0.984 \\
51\end{array}$ & $\begin{array}{l}0.985 \\
51\end{array}$ & $\begin{array}{l}0.980 \\
51\end{array}$ & $\begin{array}{c}0.991 \\
51\end{array}$ & ${ }_{51}^{n}$ & $\begin{array}{l}0.926 \\
51\end{array}$ & $\begin{array}{c}0.982 \\
51\end{array}$ & $\begin{array}{l}0.931 \\
51\end{array}$ & $\begin{array}{c}0.945 \\
51\end{array}$ & $\begin{array}{l}0.941 \\
51\end{array}$ & $\begin{array}{l}0.864 \\
51\end{array}$ \\
\hline $\begin{array}{l}\text { Trait 15: HZI_0408_R:1420183_at } \\
\text { Symbol: Lor }\end{array}$ & $\begin{array}{l}0.976 \\
51\end{array}$ & $\begin{array}{l}0.977 \\
51\end{array}$ & $\begin{array}{l}0.964 \\
51\end{array}$ & $\begin{array}{l}0.972 \\
51\end{array}$ & $\begin{array}{c}0.983 \\
51\end{array}$ & 0.974 & $\begin{array}{c}0.981 \\
51\end{array}$ & $\begin{array}{c}0.963 \\
51\end{array}$ & $\begin{array}{c}0.966 \\
51\end{array}$ & $\begin{array}{c}0.970 \\
51\end{array}$ & 0.974 & 0.974 & $\begin{array}{c}0.965 \\
51\end{array}$ & $\begin{array}{l}0.969 \\
51\end{array}$ & $\begin{array}{l}n \\
51\end{array}$ & $\frac{0.923}{51}$ & $\begin{array}{c}0.877 \\
51\end{array}$ & $\begin{array}{c}0.883 \\
51\end{array}$ & $\begin{array}{l}0.935 \\
51\end{array}$ & $\begin{array}{l}0.833 \\
51\end{array}$ \\
\hline $\begin{array}{l}\text { Trait 16: HZ1_0408_R:1429540_at } \\
\text { Symbol: Cnfn }\end{array}$ & $\begin{array}{l}0.975 \\
51\end{array}$ & 0.977 & 0.969 & 0.971 & 0.974 & $\begin{array}{c}0.986 \\
51\end{array}$ & 0.985 & 0.972 & 0.992 & $\begin{array}{c}0.980 \\
51\end{array}$ & $\begin{array}{c}0.986 \\
51\end{array}$ & $\begin{array}{l}0.972 \\
512\end{array}$ & $\begin{array}{c}0.989 \\
51\end{array}$ & $\begin{array}{l}0.994 \\
51\end{array}$ & 0.965 & ${ }_{51}^{n}$ & $\begin{array}{c}0.935 \\
51\end{array}$ & $\begin{array}{l}0.945 \\
51\end{array}$ & $\begin{array}{l}0.949 \\
51\end{array}$ & $\begin{array}{l}0.867 \\
51\end{array}$ \\
\hline $\begin{array}{l}\text { Trait 17: HZ1_0408_R:1437019_at } \\
\text { Symbol: 2200001115Rik }\end{array}$ & ${ }_{51}^{0.974}$ & $\begin{array}{l}0.975 \\
51\end{array}$ & $\begin{array}{l}0.973 \\
51\end{array}$ & $\begin{array}{c}0.974 \\
51\end{array}$ & $\underset{51}{0.973}$ & $\begin{array}{c}0.989 \\
51\end{array}$ & $\begin{array}{l}0.984 \\
51\end{array}$ & $\begin{array}{c}0.979 \\
51\end{array}$ & $\begin{array}{c}0.984 \\
51\end{array}$ & $\begin{array}{l}0.975 \\
51\end{array}$ & $\begin{array}{c}0.977 \\
51\end{array}$ & $\begin{array}{c}0.966 \\
51\end{array}$ & ${ }_{51}^{0.972}$ & $\begin{array}{l}0.981 \\
51\end{array}$ & $\begin{array}{c}0.960 \\
51\end{array}$ & $\begin{array}{l}0.984 \\
51\end{array}$ & 51 & 0.920 & $\begin{array}{l}0.911 \\
51\end{array}$ & $\begin{array}{l}0.848 \\
51\end{array}$ \\
\hline $\begin{array}{l}\text { Trait 18: HZ1_0408_R:14234944_at } \\
\text { Symbol: 2310042E22Rik }\end{array}$ & 0.972 & $\begin{array}{l}0.970 \\
51\end{array}$ & $\begin{array}{l}0.959 \\
51\end{array}$ & $\begin{array}{l}0.978 \\
51\end{array}$ & $\begin{array}{l}0.968 \\
51\end{array}$ & $\begin{array}{l}0.979 \\
51\end{array}$ & 0.986 & $\begin{array}{l}0.968 \\
51\end{array}$ & $\begin{array}{l}0.982 \\
511\end{array}$ & $\begin{array}{l}0.979 \\
51\end{array}$ & $\begin{array}{l}0.982 \\
51\end{array}$ & $\begin{array}{l}0.981 \\
51\end{array}$ & $\begin{array}{l}0.986 \\
51\end{array}$ & $\begin{array}{l}0.987 \\
51\end{array}$ & $\begin{array}{c}0.966 \\
51\end{array}$ & 0.984 & $\begin{array}{c}0.979 \\
51\end{array}$ & $\begin{array}{l}n \\
51\end{array}$ & $\begin{array}{l}0.925 \\
51\end{array}$ & $\begin{array}{l}0.886 \\
51\end{array}$ \\
\hline $\begin{array}{l}\text { Trait 19: HZ1_04088R:1453801_at } \\
\text { Symbol: } 1110038 F 21 R i k\end{array}$ & 0.972 & 0.971 & $\begin{array}{l}0.965 \\
51\end{array}$ & $\begin{array}{l}0.971 \\
51\end{array}$ & $\begin{array}{l}0.964 \\
51\end{array}$ & 0.985 & 0.984 & 0.981 & $\begin{array}{l}0.989 \\
51\end{array}$ & $\begin{array}{l}0.990 \\
51\end{array}$ & 0.991 & 0.980 & 0.984 & 0.984 & $\begin{array}{c}0.963 \\
51\end{array}$ & 0.984 & 0.980 & 0.983 & ${ }_{51}^{n}$ & $\begin{array}{l}0.917 \\
51\end{array}$ \\
\hline $\begin{array}{l}\text { Trait 20: HZ1_0408_R:1458367_at } \\
\text { Symbol: 32222401G21Rik }\end{array}$ & $\begin{array}{c}0.964 \\
51\end{array}$ & $\begin{array}{c}0.959 \\
51\end{array}$ & $\frac{0.953}{51}$ & $\begin{array}{l}0.972 \\
51\end{array}$ & $\begin{array}{c}0.952 \\
51\end{array}$ & $\stackrel{0.965}{51}$ & 0.971 & $\begin{array}{c}0.968 \\
51\end{array}$ & $\begin{array}{c}0.967 \\
51\end{array}$ & $\begin{array}{c}0.970 \\
51\end{array}$ & $\begin{array}{c}0.971 \\
51\end{array}$ & $\begin{array}{c}0.971 \\
51\end{array}$ & $\begin{array}{c}0.975 \\
51\end{array}$ & $\begin{array}{c}0.966 \\
51\end{array}$ & $\begin{array}{c}0.952 \\
51\end{array}$ & $\begin{array}{c}0.960 \\
51\end{array}$ & $\begin{array}{c}0.959 \\
51\end{array}$ & $\begin{array}{l}0.974 \\
51\end{array}$ & $\begin{array}{l}0.975 \\
51\end{array}$ & ${ }_{51}^{n}$ \\
\hline
\end{tabular}

Figure 3 The cytokeratin network. Pearson correlations (listed below the diagonal) showed very high correlations between all pairs of the 20 selected genes. Spearman Rank correlations are shown above the diagonal.

(glutaminyl-peptide cyclotransferase (glutaminyl cyclase) and Mta3 (metastasis associated 3) were suggested as potential QTGs by [20]. Another lung-specific phenotype in the GeneNetwork database is "Mycoplasmosis susceptibility, alveolar exudate" (GeneNetwork ID
10692, [21] and Cartner et al. unpublished). This trait showed a significant QTL on chromosome 10, between 105 and $130 \mathrm{Mb}$. The analysis of our lung expression data revealed 16 cis-eQTLs in the genomic interval (Table 5). Three of the cis-QTL genes have been

\begin{tabular}{|c|c|c|c|c|c|c|c|c|c|c|c|c|c|}
\hline & $\begin{array}{l}\text { Record } \\
\text { ID } \\
\text { a.d }\end{array}$ & $\begin{array}{l}\text { Symbol } \\
\text { ase }\end{array}$ & $\begin{array}{l}\text { Description } \\
\text { దE }\end{array}$ & $\begin{array}{l}\text { Location } \\
\text { Chr and Mb } \\
\text { ๓ळ }\end{array}$ & $\begin{array}{l}\text { Mean } \\
\text { Expr } \\
\text { aల }\end{array}$ & $\begin{array}{l}\text { Max } \\
\text { LRS } \\
\text { ag }\end{array}$ & $\begin{array}{l}\text { Max LRS Location } \\
\text { Chr and Mb } \\
\end{array}$ & $\begin{array}{l}\text { Sample } \\
\mathbf{r}^{\text {? }} \text { ? }\end{array}$ & $\begin{array}{l}\mathbf{N} \\
\text { Cases } \\
\text { ald }\end{array}$ & $\begin{array}{l}\text { Sample } \\
\text { s p(r)? } \\
\text { 兵 }\end{array}$ & $\begin{array}{l}\text { Lit } \\
\text { Corr } \\
\text { aeg }\end{array}$ & $\begin{array}{l}\text { Tissue } \\
\mathbf{r} \text { ? } \\
\text { ave }\end{array}$ & $\begin{array}{l}\text { Tissue } \\
\text { p(r)? }\end{array}$ \\
\hline $1 \bullet$ & 1422828_at & $C d 3 d$ & CD3 antigen, delta polypeptide & Chr9: 44.789979 & 9.770 & 13.2 & Chr7: 81.491656 & 1.000 & 51 & $10.00 e+00$ & 1.000 & 1.000 & N/A \\
\hline $2 \boxminus$ & 1452405_x_at & Tcra & T-cell receptor alpha chain & Chr14: 54.842731 & 9.754 & 12.7 & Chr11: 103.578807 & 0.917 & 51 & $10.00 e+00$ & 0.711 & 0.798 & 0.000 \\
\hline $3 \square$ & 1425396_a_at & Lck & lymphocyte protein tyrosine kinase & Chr4: 129.225782 & 9.936 & 11.9 & Chr7: 81.491656 & 0.907 & 51 & $10.00 e+00$ & 0.610 & 0.909 & 0.000 \\
\hline $4 \square$ & 1417171_at & Itk & IL2-inducible T-cell kinase; mid distal 3' UTR & Chr11: 46.138692 & 8.208 & 11.3 & Chr7: 81.491656 & 0.894 & 51 & $10.00 e+00$ & 0.619 & 0.883 & 0.000 \\
\hline $5 \square$ & 1425854_x_at & $T c r b-V 13$ & T-cell receptor beta, variable 13 & Chr6: 41.496833 & 9.767 & 12.0 & Chr7: 85.847907 & 0.879 & 51 & $10.00 e+00$ & 0.726 & 0.882 & 0.000 \\
\hline $6 \square$ & 1422105_at & Cd3e & CD3 antigen, epsilon polypeptide; distal 3' UTR & Chr9: 44.806844 & 9.656 & 8.6 & Chr7: 81.491656 & 0.872 & 51 & $0.00 e+00$ & 0.924 & 0.862 & 0.000 \\
\hline $7 \bullet$ & 1426159_x_at & $T c r b-V 13$ & T-cell receptor beta, variable 13 & Chr6: 41.488285 & 10.520 & 10.8 & Chr7: 85.847907 & 0.865 & 51 & $0.00 e+00$ & 0.726 & 0.882 & 0.000 \\
\hline $8 \boxminus$ & 1426113_x_at & Tcra & T-cell receptor alpha chain & Chr14: 54.843469 & 10.140 & 10.6 & Chr11: 101.112194 & 0.864 & 51 & $0.00 \mathrm{e}+00$ & N/A & 0.798 & 0.000 \\
\hline $9 \square$ & 1419178_at & $C d 3 g$ & $\mathrm{CD} 3$ antigen, gamma polypeptide & Chr9: 44.777916 & 8.820 & 11.5 & Chr9: 80.917762 & 0.863 & 51 & $0.00 e+00$ & 0.976 & 0.844 & 0.000 \\
\hline $10 \square$ & 1452205_x_at & $T c r b-V 13$ & T-cell receptor beta, variable 13 & Chr6: 41.488510 & 9.520 & 12.5 & Chr7: 85.847907 & 0.861 & 51 & $0.00 e+00$ & 0.726 & 0.882 & 0.000 \\
\hline $11 \boxminus$ & 1425226_x_at & $T c r b-V 13$ & T-cell receptor beta, variable 13 & Chr6: 41.488321 & 10.198 & 11.1 & Chr7: 85.847907 & 0.860 & 51 & $0.00 e+00$ & 0.726 & 0.882 & 0.000 \\
\hline $12 \square$ & 1416107_at & Hmp19 & $\begin{array}{l}\text { HMP19 protein, neuron specific gene family } \\
\text { member } 2 \text { (hypothalamus golgi apparatus } \\
\text { expressed } 19 \mathrm{kDa} \text { protein, dopamine receptor } \\
\text { binding); distal 3' UTR }\end{array}$ & Chr11: 31.958642 & 8.400 & 13.0 & Chr7: 81.491656 & 0.850 & 51 & $0.00 e+00$ & 0.306 & N/A & N/A \\
\hline $13 \square$ & 1460651_at & Lat & linker for activation of T cells & Chr7: 133.507917 & 9.211 & 14.0 & Chr7: 90.186486 & 0.839 & 51 & $0.00 e+00$ & 0.667 & 0.878 & 0.000 \\
\hline $14 \square$ & 1426772_x_at & $T c r b-V 13$ & T-cell receptor beta, variable 13 & Chr6: 41.496891 & 10.006 & 10.1 & Chr7: 85.847907 & 0.837 & 51 & $10.00 e+00$ & 0.726 & 0.882 & 0.000 \\
\hline $15 \square$ & 1434295_at & Rasgrp1 & RAS guanyl releasing protein 1; distal 3' UTR & Chr2: 117.105846 & 8.530 & 11.5 & Chr12: 101.866283 & 0.833 & 51 & $2.22 \mathrm{e}-16$ & 0.609 & 0.452 & 0.020 \\
\hline $16 \square$ & 1437249_at & Scap1 & $\begin{array}{l}\text { src family associated phosphoprotein } 1 \text {; last three } \\
\text { exons }\end{array}$ & Chr11: 96.592455 & 8.072 & 14.2 & Chr7: 89.127385 & 0.822 & 51 & $6.66 \mathrm{e}-16$ & 0.559 & N/A & N/A \\
\hline $17 \ominus$ & 1435227_at & $B c / 11 b$ & B-cell leukemia/lymphoma 11B; distal 3' UTR & Chr12: 109.150912 & 8.565 & 10.1 & Chr7: 81.491656 & 0.818 & 51 & $1.55 \mathrm{e}-15$ & 0.580 & 0.413 & 0.036 \\
\hline $18 \square$ & 1451910_a_at & $C d 6$ & CD6 antigen & Chr19: 10.864137 & 7.856 & 9.3 & Chr7: 125.263073 & 0.815 & 51 & $2.66 \mathrm{e}-15$ & 0.733 & 0.864 & 0.000 \\
\hline $19 \square$ & 1438392_at & 4833413G11Rik & $\begin{array}{l}4833413 \text { G11 Rik (Cd247 antigen-associated); } 3^{\prime} \\
\text { UTR (in Cd3z intron 1) }\end{array}$ & Chr1: 167.735938 & 7.114 & 10.5 & Chr7: 81.491656 & 0.815 & 51 & $2.66 \mathrm{e}-15$ & N/A & N/A & N/A \\
\hline $20 \square$ & 1418353_at & $C d 5$ & CD5 antigen & Chr19: 10.792689 & 7.984 & 11.3 & Chr12: 118.628399 & 0.805 & 51 & $1.27 e-14$ & 0.789 & 0.708 & 0.000 \\
\hline
\end{tabular}

Figure 4 Gene signatures for T-cells. List of the strongest correlates for Cd3d (probe set 1422828_at), all correlated at $p<10^{-13}$. 


\begin{tabular}{|c|c|c|c|c|c|c|c|c|c|c|c|c|c|}
\hline & $\begin{array}{l}\text { Record } \\
\text { ID } \\
\text { WE }\end{array}$ & $\begin{array}{l}\text { Symbol } \\
\text { ae }\end{array}$ & $\begin{array}{l}\text { Description } \\
\text { ae }\end{array}$ & $\begin{array}{l}\text { Location } \\
\text { Chr and Mb } \\
\text { Ge }\end{array}$ & $\begin{array}{l}\text { Mean } \\
\text { Expr } \\
\text { ape }\end{array}$ & $\begin{array}{l}\text { Max } \\
\text { LRS } \\
\text { a }\end{array}$ & $\begin{array}{l}\text { Max LRS Location } \\
\text { Chr and Mb }\end{array}$ & $\begin{array}{l}\text { Sample } \\
\text { r? }\end{array}$ & $\begin{array}{l}\mathbf{N} \\
\text { Cases } \\
\text { ae }\end{array}$ & $\begin{array}{l}\text { Sample } \\
\mathrm{p}(\mathrm{r}) \text { ? }\end{array}$ & $\begin{array}{l}\text { Lit } \\
\text { Corr }\end{array}$ & $\begin{array}{l}\text { Tissue } \\
\mathbf{r}\end{array}$ & $\begin{array}{l}\text { Tissue } \\
\text { p(r)? }\end{array}$ \\
\hline $1 \square$ & 1450570_a_at & Cd19 & CD19 antigen & Chr7: 133.551983 & 9.343 & $10.1 \mathrm{C}$ & Chr16: 73.748201 & 1.000 & 51 & $0.00 e+00$ & 1.000 & 1.000 & N/A \\
\hline $2 \square$ & 1417640_at & $C d 79 b$ & CD79B antigen & Chr11: 106.172725 & 10.376 & 11.8 & Chr5: 133.538653 & 0.917 & 51 & $0.00 e+00$ & 0.811 & 0.914 & 0.000 \\
\hline $3 \square$ & 1429889_at & Faim3 & Fas apoptotic inhibitory molecule 3 & Chr1: 132.774829 & 9.773 & 12.6 & Chr6: 88.537080 & 0.909 & 51 & $0.00 e+00$ & 0.462 & 0.887 & 0.000 \\
\hline $4 \square$ & 1418830_at & Cd79a & CD79A antigen (immunoglobulin-associated alpha) & Chr12: 53.180027 & 9.950 & 15.4 & Chr10: 13.407601 & 0.891 & 51 & $0.00 e+00$ & 0.858 & 0.961 & 0.000 \\
\hline $5 \square$ & 1422775_at & $B \mid k$ & B lymphoid kinase (oncogene); last exon and proximal half of $3^{\prime}$ UTR & Chr14: 63.991841 & 8.724 & 13.1 & Chr6: 88.537080 & 0.865 & 51 & $0.00 e+00$ & 0.713 & 0.928 & 0.000 \\
\hline $6 \square$ & 1420994_at & B3gnt5 & $\begin{array}{l}\text { UDP-GlcNAc: betaGal beta-1,3-N-acetylglucosaminyitransferase 5; } \\
\text { distal and far 3' UTR }\end{array}$ & Chr16: 19.771998 & 8.785 & 12.8 & Chr10: 12.729006 & 0.847 & 51 & $0.00 e+00$ & 0.353 & 0.514 & 0.007 \\
\hline $7 \bullet$ & 1419768_at & Cd22 & CD22 antigen & Chr7: 31.650937 & 10.302 & 15.8 & Chr7: 31.950330 & 0.846 & 51 & $0.00 e+00$ & 0.869 & 0.947 & 0.000 \\
\hline $8 \square$ & 1419907_s_at & Fcrla & Fc receptor-like A; expressed sequence BB219290 & Chr1: 172.847803 & 7.411 & 16.0 & Chr15: 91.723348 & 0.837 & 51 & $0.00 e+00$ & N/A & 0.963 & 0.000 \\
\hline $9 \square$ & 1422003_at & Blr1 & Burkitt lymphoma receptor 1 & Chr9: 44.320024 & 8.601 & 13.1 & Chr6: 88.537080 & 0.834 & 51 & $0.00 e+00$ & 0.663 & 0.895 & 0.000 \\
\hline $10 \boxminus$ & 1419206_at & Cd37 & CD37 antigen & Chr7: 52.489289 & 10.082 & 11.3 & Chr10: 13.407601 & 0.829 & 51 & $2.22 \mathrm{e}-16$ & 0.634 & 0.871 & 0.000 \\
\hline $11 \boxminus$ & 1460407_at & Spib & Spi-B transcription factor (Spi-1/PU.1 related) & Chr7: 51.781391 & 9.152 & 10.4 & Chr1: 108.290874 & 0.829 & 51 & $2.22 \mathrm{e}-16$ & 0.716 & 0.967 & 0.000 \\
\hline $12 \boxminus$ & 1423182_at & Tnfrsfi3b & tumor necrosis factor receptor superfamily, member $13 b$ & Chr11: 60.962284 & 9.318 & 20.4 & Chr6: 88.537080 & 0.812 & 51 & $4.44 \mathrm{e}^{-15}$ & 0.747 & 0.792 & 0.000 \\
\hline $13 \square$ & 1460419_a_at & Prkcb & protein kinase $\mathrm{C}$, beta; distal 3' UTR & Chr7: 129.777363 & 9.675 & 13.2 & Chr5: 147.658807 & 0.805 & 51 & $1.38 \mathrm{e}-14$ & 0.432 & N/A & N/A \\
\hline $14 \square$ & 1456632_at & BCI11a & $\begin{array}{l}\text { B-cell CLL/lymphoma 11A (zinc finger protein); distal 3' UTR or last } \\
\text { intron }\end{array}$ & Chr11: 24.066781 & 7.033 & 12.3 & Chr10: 12.729006 & 0.802 & 51 & $2.00 \mathrm{e}-14$ & 0.563 & 0.648 & 0.000 \\
\hline $15 \square$ & 1425736_at & Cd37 & CD37 antigen & Chr7: 52.493149 & 9.102 & 15.2 & Chr10: 12.729006 & 0.796 & 51 & $4.71 \mathrm{e}-14$ & 0.634 & 0.871 & 0.000 \\
\hline $16 \square$ & 1419307_at & Tnfrsf13c & tumor necrosis factor receptor superfamily, member $13 c$ & Chr15: 82.052242 & 8.329 & 10.1 & Chr8: 91.144186 & 0.796 & 51 & $5.20 \mathrm{e}-14$ & 0.804 & 0.970 & 0.000 \\
\hline $17 \boxminus$ & 1456328_at & A530094C12Rik & RIKEN CDNA A530094C12 gene & Chr3: 135.716431 & 9.356 & 10.7 & Chr15: 70.982535 & 0.789 & 51 & $1.27 \mathrm{e}-13$ & 0.651 & N/A & N/A \\
\hline $18 \square$ & 1419406_a_at & Bcl11a & B-cell CLL/ymphoma 11A (zinc finger protein) & Chr11: 24.072849 & 7.832 & 12.8 & Chr15: 95.144975 & 0.788 & 51 & $1.56 \mathrm{e}-13$ & 0.563 & 0.648 & 0.000 \\
\hline $19 \square$ & 1438995_at & Pan $\times 3$ & pannexin 3 & Chr13: 24.747062 & 8.779 & 10.2 & Chr15: 95.144975 & 0.783 & 51 & $2.85 \mathrm{e}-13$ & 0.222 & 0.056 & 0.786 \\
\hline $20 \bullet$ & 1423478_at & Prkcbl & protein kinase $\mathrm{C}$, beta 1 ; mid $3^{\prime}$ UTR & Chr7: 129.771598 & 7.297 & 13.2 & Chr5: 147.658807 & 0.781 & 51 & $3.74 \mathrm{e}-13$ & 0.432 & 0.431 & 0.028 \\
\hline
\end{tabular}

Figure 5 Gene signatures for B-cells. List of the strongest correlates for Cd19 (probe set 1450570_at), all correlated at p < $10^{-12}$.

associated previously with immune functions and thus represent suitable candidates to regulate this trait: Chst (carbohydrate (keratan sulfate Gal-6) sulfotransferase 1) was found to exhibit a critical role in lymphocyte trafficking during chronic inflammation [22]. The transcription factor Maf (avian musculoaponeurotic fibrosarcoma (v-maf) AS42 oncogene homolog) was shown to play a role in the transcriptional regulation of cytokine expression and immune cell markers, e.g. [23-29]. Nrp1 (neuropilin 1) has been primarily described as neuronal receptor but appears also to play a role in the primary immune response and formation of the immunological synapse [30,31].

\section{Cis- and trans-eQTLs}

We then performed a search for eQTLs on a global level, for all probe sets. In this analysis 5,214 cis-and 15,485 trans-regulated genes were identified at an LRS threshold of 12 (Table 6 and Figure 6). When the LRS threshold was increased to 50, 1,332 cis-regulated genes were found, whereas the number of trans-regulated genes was reduced to 15 . This observation indicates that many of the trans-eQTL showed a much lower significance value than the cis-eQTL. Next, we present examples for one cis- and one trans-eQTL. A strong eQTL was detected on chromosome 14, at 52 megabases (Mb; Figure 7B) regulating the expression levels of $A n g$ (angiogenin, ribonuclease, RNase A family, 5) (Figure 7A). Since Ang is located at the same position as the eQTL (51.7 Mb on chromosome 14) it represents a ciseQTL. Furthermore, a strong eQTL was found on chromosome 12 regulating the expression levels of the Cyp1a1 gene (cytochrome P450, family 1, subfamily a, polypeptide 1) (Figure 7C,D). Cyp1a1 is located on chromosome 9 and the corresponding eQTL was found on chromosome 12 (trans-eQTL). The eQTL significance interval contained nine genes, four of which were expressed in lung at a level above 10. Ahr (aryl-hydrocarbon receptor) was one of the four genes and was at the top of the QTL peak (Figure 8). It is the most likely candidate for Cyp1a1 regulation. In conclusion, our data set contained a large number of genes whose expression levels are likely to be influenced by allelic variations in the genomes of C57BL/6J and DBA/2J. Therefore, the

Table 4 Cis-eQTLs identified in QTL inteval on chromosome 2 for influenza susceptibility

\begin{tabular}{|c|c|c|c|c|c|}
\hline Probe set & Symbol & Description & Location (Chr, Mb) & Mean Expr & Max LRS \\
\hline 1423602_at & Traf1 & Tnf receptor-associated factor 1 & Chr2: 34.798805 & 9,28 & 21,1 \\
\hline 1419407_at & $H C$ & hemolytic complement & Chr2: 34.838908 & 12,00 & 82,7 \\
\hline 1441635_at & Nr6al & nuclear receptor subfamily 6, group A, member 1 & Chr2: 38.736451 & 7,51 & 20,2 \\
\hline 1455743_at & $\mathrm{O} / \mathrm{fm} / 2 \mathrm{a}$ & olfactomedin-like $2 \mathrm{~A}$ & Chr2: 38.816929 & 8,28 & 63,2 \\
\hline 1430379_at & Zfh $\times 1 b$ & zinc finger homeobox $1 \mathrm{~b}$ & Chr2: 44.931019 & 9,08 & 82,4 \\
\hline 1438516_at & Rif1 & Rap1 interacting factor 1 & Chr2: 51.975068 & 8,03 & 38,8 \\
\hline 1444530_at & Neb & nebulin & Chr2: 51.991339 & 8,14 & 86,9 \\
\hline
\end{tabular}

For each gene, only the highest LRS is shown. Mean Expr: mean expression in lung for BXD strains. 
Table 5 Cis-eQTLs identified in QTL on chromosome 8 for Mycoplasmosis susceptibility trait

\begin{tabular}{|c|c|c|c|c|c|}
\hline Probe set & Symbol & Description & $\begin{array}{l}\text { Location (Chr, } \\
\mathrm{Mb})\end{array}$ & $\begin{array}{l}\text { Mean } \\
\text { Expr }\end{array}$ & $\begin{array}{l}\text { Max } \\
\text { LRS }\end{array}$ \\
\hline 1435883_at & AW413431 & expressed sequence AW413431 & Chr8: 109.374192 & 8,27 & 37 \\
\hline 1436986_at & Sntb2 & syntrophin, basic 2 & Chr8: 109.537595 & 6,94 & 23,6 \\
\hline 1437003_at & 5730419l09Rik & RIKEN cDNA 5730419109 gene & Chr8: 109.543026 & 9,79 & 24,6 \\
\hline 1451052_at & $\operatorname{Cog} 8$ & component of oligomeric golgi complex 8 & Chr8: 109.570082 & 10,35 & 23,7 \\
\hline 1417766_at & 1810044O22Rik & RIKEN cDNA $1810044 \mathrm{O} 22$ gene & Chr8: 109.710789 & 11,80 & 38 \\
\hline 1429725_at & Atbfi & AT motif binding factor 1 & Chr8: 111.481987 & 8,84 & 70,1 \\
\hline 1453393_a_at & Chst4 & carbohydrate (chondroitin 6/keratan) sulfotransferase 4 & Chr8: 112.553165 & 7,33 & 71,9 \\
\hline 1427513_at & Nudt7 & nudix (nucleoside diphosphate linked moiety X)-type motif 7 & Chr8: 116.678269 & 6,95 & 22,7 \\
\hline 1446412_at & Wwox & WW domain-containing oxidoreductase & Chr8: 117.339587 & 7,46 & 94,7 \\
\hline 1444073_at & Maf & $\begin{array}{l}\text { avian musculoaponeurotic fibrosarcoma (v-maf) AS42 oncogene } \\
\text { homolog }\end{array}$ & Chr8: 118.225461 & 7,93 & 121 \\
\hline 1449964_a_at & Mlycd & $\begin{array}{l}\text { malonyl-CoA decarboxylase (test Mendelian in BXDs with high DBA/2J } \\
\text { allele) }\end{array}$ & Chr8: 121.934407 & 9,63 & 34,8 \\
\hline 1418856_a_at & Fanca & Fanconi anemia, complementation group A & Chr8: 125.792224 & 7,98 & 78,5 \\
\hline 1460109_at & D8Ertd325e & DNA segment, Chr 8, ERATO Doi 325, expressed & Chr8: 125.915951 & 7,60 & 89,8 \\
\hline 1449307_at & Dbndd1 & dysbindin (dystrobrevin binding protein 1) & Chr8: 126.029666 & 7,14 & 24,1 \\
\hline 1446982_at & Pard3 & par-3 (partitioning defective 3) homolog (C. elegans) & Chr8: 130.036847 & 8,02 & 87,9 \\
\hline 1448944_at & Nrpl & neuropilin 1 & Chr8: 131.027919 & 11,95 & 42,4 \\
\hline
\end{tabular}

For each gene, only the highest LRS is shown. Mean Expr: mean expression in lung for BXD strains.

presence of pairs of regulated genes and their corresponding eQTLs predicts possible regulatory interactions and will allow searching for yet unknown regulatory networks.

\section{Discussion}

Here, we performed global gene expression profiling in eight inbred mouse strains and a cohort of BXD recombinant inbred strains from whole lung tissues. Our studies identified several lung-specific genes, large variations in gene expression levels, and a strong heritability in many gene expression traits. Correlation analysis of gene expression and genotypes identified potential gene interaction networks, pairs of trans- and ciseQTLs, and genes with cis-eQTLs that may represent candidate genes involved in susceptibility to respiratory infections. In addition, one specific gene interaction pathway was identified in which $A h r$ regulates the Cyp1a1 gene.

Using tissue correlations of gene expression patterns across the BXD strains, we identified 16 genes with a

Table 6 Amount of cis- and trans-regulated transcripts for different significance thresholds

\begin{tabular}{ccr}
\hline Threshold (LRS) & No. of cis eQTLs & No. of trans eQTLs \\
\hline 12 & 5,214 & 15,485 \\
16 & 4,391 & 3,149 \\
20 & 3,666 & 536 \\
30 & 2,500 & 48 \\
50 & 1,332 & 15 \\
\hline
\end{tabular}

highly restricted expression in the lung of which 14 could be validated by comparison to the BioGPS database [19]. The second most strongly expressed gene in the lung tissues was $S f t p c$ which has been shown to play a role in lung development and the prevention of pneumonitis and emphysema [32,33]. Also, Sftpc deficiency increases the severity of respiratory syncytial virusinduced pulmonary inflammation [34]. Furthermore, Scgbla1 and Ager were amongst the five most strongly expressed genes. Scgb1a1 is expressed in lung clara cells and its deficiency results in enhanced susceptibility to environmental agents [35]. Scgb3a1 (secretoglobin, family 3A, member 1) and Scgb3a2 (secretoglobin, family $3 \mathrm{~A}$, member 2) were shown by others to be highly expressed in the lung and lower levels in other organs [36]. Scgb3a2 is down-regulated in inflamed airways [37] and plays an important role in lung development [38]. Sftpb (surfactant associated protein B (nonciliated bronchiolar and alveolar type 2 cell signature) is a hydrophobic peptide which enhances the surface properties of pulmonary surfactant and is expressed in nonciliated bronchiolar and aleveolar type 2 cells [39]. Maintenance of $S f t p b$ expression is critical for survival during acute lung injury [40] and reduction of alveolar expression causes surfactant dysfunction and respiratory failure [41]. Plunc (palate, lung, and nasal epithelium carcinoma associated) is expressed in the oral, lingual, pharyngeal and respiratory epithelia [42] and members of the Plunc gene family are thought to pay a role in the innate immune response [43]. The presence of Plunc protein in the lung decreases the levels of Mycoplasma 


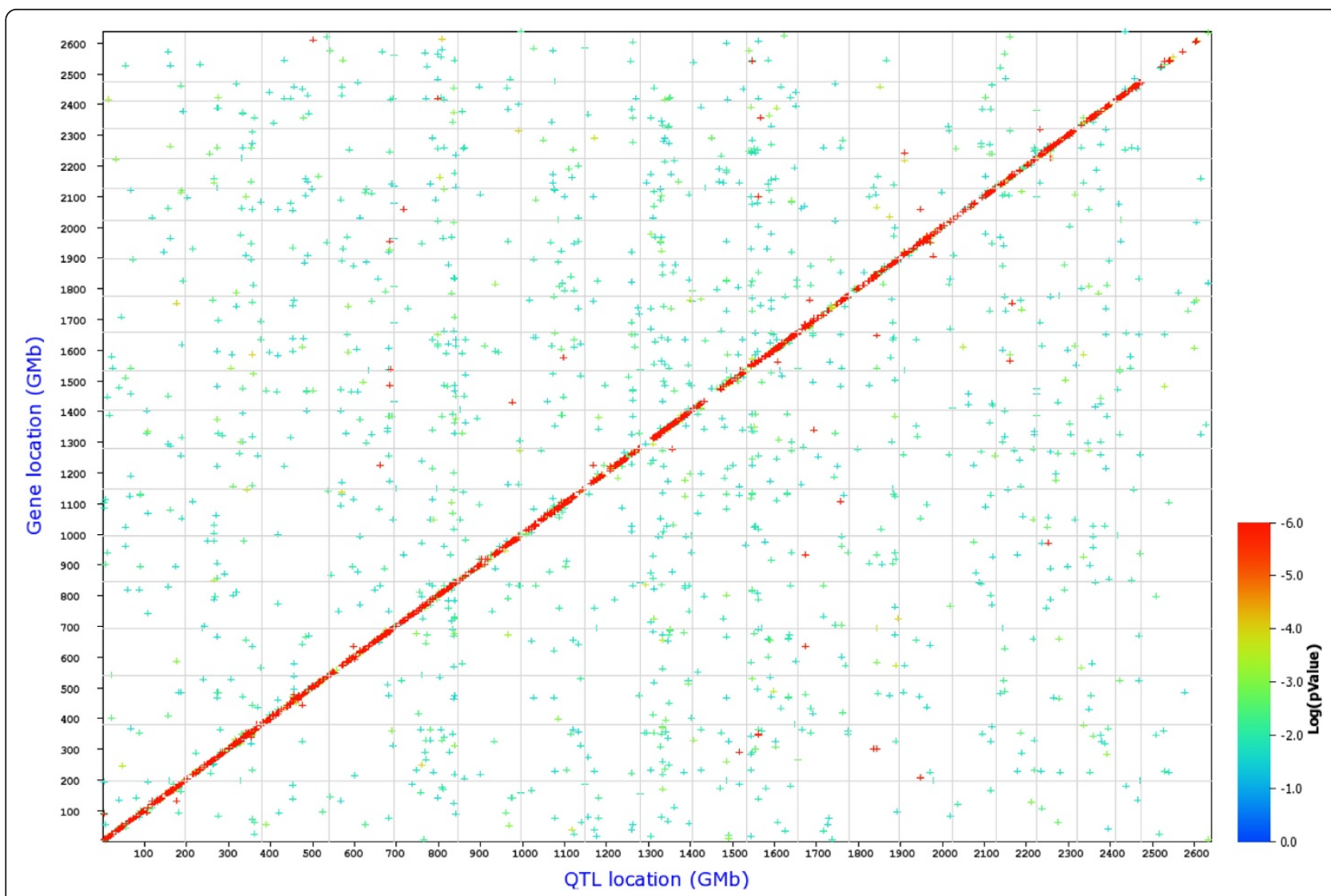

Figure 6 Genome-wide graph of cis- and trans-eQTLs. The positions of the eQTLs are plotted against the locations of the corresponding transcript along the genome. Cis-regulated genes are located at the diagonal, all other dots represent trans-regulated genes. The significance level of each QTL is indicated by the color.

pneumoniae and its levels are reduced in allergic inflammatory conditions [44]. Thus, the lung data set allowed us to find important genes that are expressed primarily in the lung and are important for lung homeostasis and prevention of disease.

It should be noted that our analysis of genes with "restricted expression to the lung" is not ex-clusive; it only refers to the tissues that are represented in GeneNetwork and BioGPS. Also, the analysis performed here should not be considered to be comprehensive. More sophisticated approaches may be employed to identify additional genes which also fulfill the criterion of "lungrestricted" expression.

Furthermore, genes may not be apparent in the lung transcriptome because they are expressed only in a small fraction of cells within the lung. This issue of dilution of expression signals is an important one and we have studied it in several tissues with considerable care (eye, retina, and numerous brain regions) using the same genetic methods and the same array platform. We were consistently able to detect expression of genes that are only expressed in very small cell subpopulations
$(<0.1 \%)$ such as rare amacrine cell subclasses in the retina [8] or very rare oxytocin-expressing neurons $(<2000)$ in whole brain samples. The reason for the increased sensitivity is that with such large sample sizes ( $\sim 70$ lung arrays) the signal-to-noise ratios are much better than standard studies using Affymetrix arrays. These stuides typically use far fewer arrays and do not use genetic methods to "validate" the source of signal.

The strong signal for hemoglobin and lymphocytespecific genes clearly showed that gene ex-pression patterns of circulating blood cells are readily detectable in the lung transcriptome. This raises the question if an organ should be studied with or without containing blood. The correct answer to this question depends of course on the particular circumstances. However, we feel strongly that a global systems and genetic approach requires the analysis of the entire organ. The expression of genes is not cell-autonomous and depends on cellular micro envi-ronment, physical factors (gas pressure and gradients, etc), pathogen exposure, and many types of interactions. These factors also influence the expression of genes in blood cells. Therefore, we think that it is 

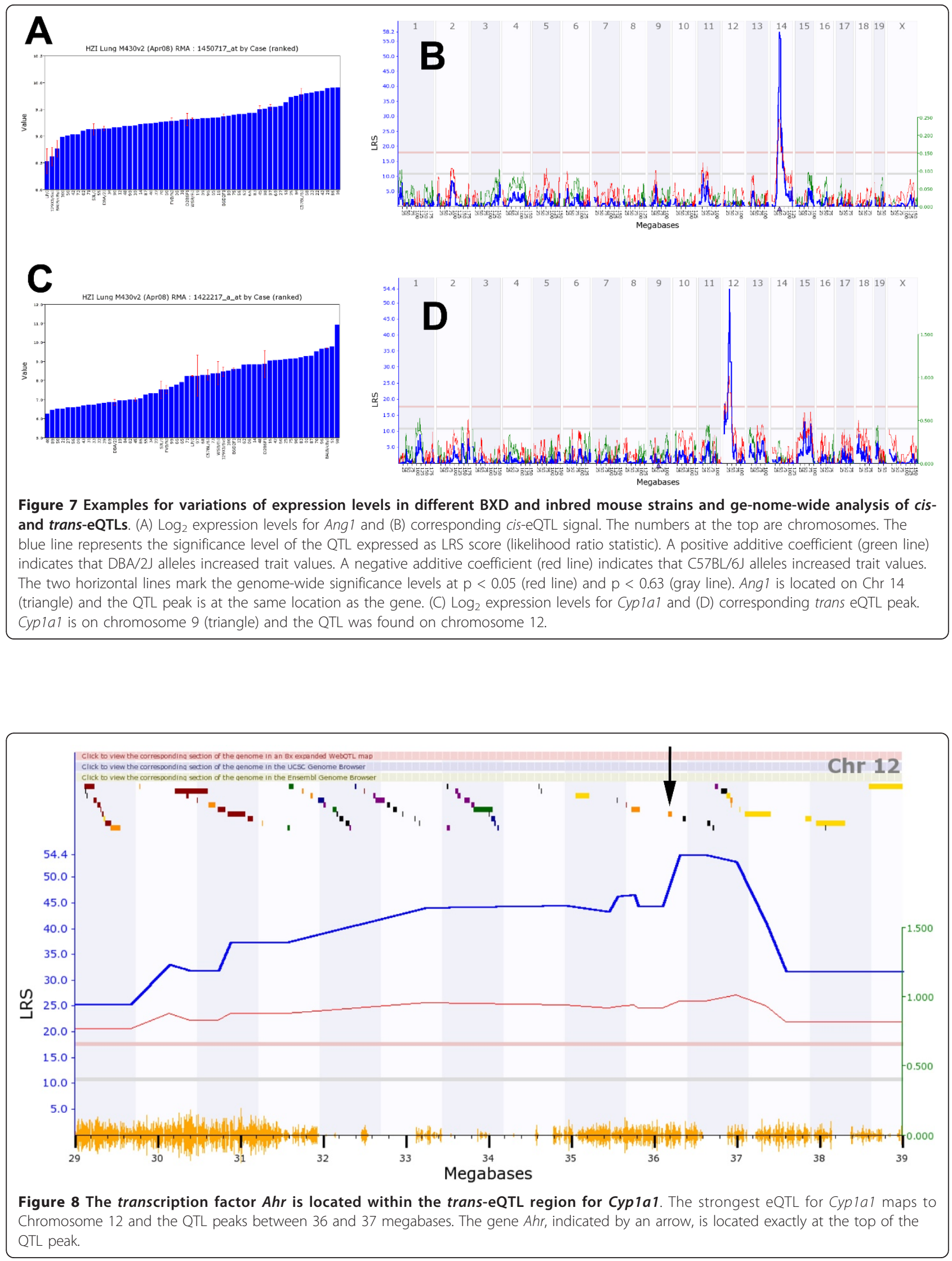
imperative to look simultaneously at all cells in a function unit: in this case the whole lung plus its containing blood.

In conclusion, the combined analysis of expression levels and correlations in a variety of tissues tissue allowed us to determine genes with restricted or preferential expression in the lung. For several of these genes, an important function in the lung has been described and the same may be assumed for the others. This information will also contribute to a better understanding of the biological function of these genes.

Many phenotypic traits have been studied for the BXD mouse populations and several QTLs were identified which influence diseases or vulnerability in the lung. The detection of cis eQTLs in the very same tissue is one method to identify potential candidate genes under the QTL which may causally influence the trait. Here, we investigated two traits in more detail, susceptibility to influenza virus and susceptibility to mycoplasmosis. Several cis-eQTLs were found in the corresponding QTL regions and in each case, genes could be identified with a presumed role in the host immune defense (discussed already in the results section). Thus, the study of cis-eQTLs in our data set may provide valuable candidates for other quantitative trait genes that influence important lung phenotypes. Furthermore, we found 13 BXD lines with low expression signals for Krt4, Krt13 and Krtdap. Krt4 and Krt13 have been shown to be responsible for White sponge nevus (WSN), also known as Cannon's disease, which is an autosomal dominant skin condition in humans [45-47]. We propose that the 13 mouse strains have genetic alterations which result in low transcript levels of these genes and they may represent a good model for Cannon's disease. It should be noted, however, that no cis-eQTLs found were found for any of the Krt genes.

We also identified a set of genes for which the expression levels correlated highly with members of the $\mathrm{Klr}$ gene family. Klra3 and Klrg1 are killer cell lectin-like receptors that are exclusively expressed on natural killer cells (NK cells). NK cells form a major component of the innate immune system and kill cells by releasing small cytoplasmic granules of proteins called perforins and granzymes [48]. Both Gzma and Prf1 were in the gene network that we identified. In addition, correlations can also be used to expand already known gene networks in specific cell populations. When starting with the $C d 3 \mathrm{~T}$ cell marker and calculating correlations with all other transcripts measured, we identified a strongly correlated network of genes, in which most of the genes were known as $\mathrm{T}$ cell markers or to be involved in $\mathrm{T}$ cell activation or homeostasis. In a similar way, when starting with the $C d 19$ B cell marker, we could identify a strongly correlated network of B cell signature genes. The analysis of these $\mathrm{T}$ cell and $\mathrm{B}$ cell expression signatures in the Bi-oGPS data base with expression profiles in mouse tissues revealed that indeed $>90 \%$ of the $\mathrm{T}$ and $\mathrm{B}$ cell markers were specifically expressed in either $\mathrm{T}$ or B cells. Furthermore, most of the $\mathrm{T}$ and $\mathrm{B}$ cell signature genes represented genes with known function in $\mathrm{B}$ and $\mathrm{T}$ cell differentiation, activation and homeostasis. For example, the $\mathrm{T}$ cell signature included genes encoding subunits of the $\mathrm{T}$ cell receptor: $C d 3 d$ (CD3 antigen, delta po-lypeptide), Cd3g (CD3 antigen, gamma polypeptide), Tcra (T-cell receptor alpha chain) and Tcrb-V13 (T-cell receptor beta, variable 13) and Lat (linker for activation of T cells) which are involved in $\mathrm{T}$ cell activation. The $\mathrm{B}$ cell signature contained components of the $\mathrm{B}$ cell antigen receptor complex, $C d 19$ (CD19 antigen) and Cd79a (CD79A antigen (immunoglobulin-associated alpha)), as well as Blk (B lymphoid kinase) tyrosine kinase which is associated with the receptors. Also, the correlations for both signatures in the spleen expression data set in GeneNetwork could indeed confirm that the signatures were strongly correlated (data not shown). In summary, these studies demonstrate that correlation analyses are able to identify genes which very likely interact in a common network or biological process. The approach used here may thus have a great potential to identify new networks and biological processes in the lung. In addition, starting with a known bona-fide cell-specific gene and then analyzing gene expression values across strains, it is possible to identify a set of highly correlated genes. These gene sets genes can now be used as cell-specific signature genes in complex transcriptome studies, e.g. to detect infiltrating immune cells in the lungs after infection.

The genetic mapping of lung expression profiles revealed many cis- and trans-eQTLs, indicating that many gene expression patterns in lung have a strong genetic component. Trans-eQTLs allow the identification of gene-gene regulatory networks. As an example, we found that the transcription factor $A h r$ was present in a trans-eQTL region detected for the Cyp1a1 gene. $A h r$ is a transcription factor known to induce Cyp 1 al transcription levels after ligand binding [49-51]. Six binding sites for the Ahr receptor ligand have been revealed in the 700-basepair DNA domain upstream of Cyp1a1 [52]. However, a critical leucine-to-proline substitution in $A h r$ results in a 15 to 20 -fold reduction in the binding affinity of the proline variant found in DBA/ 2J compared to the leucine variant found in C57BL/6J [53]. Indeed, in our data set, expression values for Cyp1a1were low for BXD strains carrying the DBA/2J allele at the $A h r$ locus and high for the strains carrying the C57BL/6J allele. Since $A h r$ is not cis-regulated in lung, the downstream effects appear to be only caused by changes in Ahr protein binding affinity. Although the 
interaction between Cypla1 and Ahr as such is not a new finding, it is quite remarkable that the interaction becomes apparent in lungs which were not exposed to an inducing xenobiotic. Furthermore, we do not see this relationship in several other tissues, such as liver. Therefore, our observation suggests that in the lung, which is potentially exposed to many xenobiotics, the Ahr receptor may always be activated at a low level. Alternatively, Ahr expression may be stimulated by yet unknown ligands that are also present under normal environmental conditions.

\section{Conclusions}

Here, we showed that whole genome expression analysis of the lungs from a large set of strains of the BXD mouse population can be exploited to identify important gene regulatory networks. We found a large number of expression correlations and QTLs which can be further investigated to better understand molecular interaction networks in the lung. The search for cis-eQTLs in genomic intervals that were identified previously as QTLs for infectious diseases revealed several quantitative trait candidate genes. In addition, we demonstrated that the analysis of gene expression correlations, starting with a few cell-specific genes, could identify a larger set of genes which allows detecting the presence of $\mathrm{B}$ and $\mathrm{T}$ cells within the transcriptome of the whole lung. Such expression signatures will be very important to follow normal and abnormal host responses during infections and other diseases of the lung.

\begin{abstract}
Acknowledgements
This work was supported by intra-mural grants from the HelmholtzAssociation (Program "Infection and Immunity") and a research grant "FluResearchNet" (No. 01KI07137) from the German Ministry of Education and Research to KS. RWW acknowledges the support of the UTHSC Center for Integrative and Translational Genomics and NIH grant P20DA21131 and U01AA13499, and LL was supported by the NIH grant U01AA014425. We thank Dr. Yan Jiao and Weikuan Gu at UTHSC and the VA Medical Center, Memphis, for running the Affymetrix arrays in their core facility. We also thank the GeneNetwork development team, including Arthur Centeno, Xiaodong Zhou, Ning Liu, Zachary Sloan, and Lei Yan, for their help in integrating and error-checking the lung transcriptome data. We also thank Samuel C. Cartner for making the data on the Mycoplasmosis susceptibility phenotype available to us prior to publication.
\end{abstract}

\section{Author details}

${ }^{1}$ Department of Infection Genetics, Helmholtz Centre for Infection Research \& University of Veterinary Medicine Hannover, Inhoffenstr. 7, D-38124 Braunschweig, Germany. ${ }^{2}$ Department of Anatomy and Neurobiology, University of Tennessee Health Science Center, Memphis, Tennessee, USA. ${ }^{3}$ Jiangsu Key Laboratory of Neuroregeneration, Nantong University, Nantong, China.

\section{Authors' contributions}

RA performed the bioinformatics analysis and wrote the manuscript. KS designed the experiments, performed the bioinformatics analysis and wrote the manuscript. $L L$ and RWW prepared the study material and supervised the expression array studies. RW contributed to writing of the manuscript. All authors have read and approved the final manuscript.

\section{Competing interests}

The authors declare that they have no competing interests.

Received: 14 January 2011 Accepted: 2 May 2011 Published: 2 May 2011

\section{References}

1. Schughart K: SYSGENET: a meeting report from a new European network for systems genetics. Mamm Genome 2010, 21(7-8):331-336.

2. Morahan G, Peeva V, Mehta M, Williams R: Systems genetics can provide new insights in to immune regulation and autoimmunity. J Autoimmun 2008, 31(3):233-236.

3. Threadgill DW, Hunter KW, Williams RW: Genetic dissection of complex and quantitative traits: from fantasy to reality via a community effort. Mamm Genome 2002, 13(4):175-178.

4. Alberts R, Fu J, Swertz MA, Lubbers LA, Albers CJ, Jansen RC: Combining microarrays and genetic analysis. Brief Bioinform 2005, 6(2):135-145.

5. Chesler EJ, Lu L, Shou S, Qu Y, Gu J, Wang J, Hsu HC, Mountz JD, Baldwin NE, Langston MA, et al: Complex trait analysis of gene expression uncovers polygenic and pleiotropic networks that modulate nervous system function. Nat Genet 2005, 37(3):233-242.

6. Jansen RC, Nap JP: Genetical genomics: the added value from segregation. Trends Genet 2001, 17(7):388-391

7. Rosen GD, Pung CJ, Owens CB, Caplow J, Kim H, Mozhui K, Lu L, Williams RW: Genetic modulation of striatal volume by loci on Chrs 6 and 17 in BXD recombinant inbred mice. Genes Brain Behav 2009, 8(3):296-308.

8. Geisert EE, Lu L, Freeman-Anderson NE, Templeton JP, Nassr M, Wang X, Gu W, Jiao Y, Williams RW: Gene expression in the mouse eye: an online resource for genetics using 103 strains of mice. Mol Vis 2009, 15:1730-1763.

9. Gaglani SM, Lu L, Williams RW, Rosen GD: The genetic control of neocortex volume and covariation with neocortical gene expression in mice. BMC Neurosci 2009, 10:44

10. Gatti D, Maki A, Chesler EJ, Kirova R, Kosyk O, Lu L, Manly KF, Williams RW, Perkins A, Langston MA, et al: Genome-level analysis of genetic regulation of liver gene expression networks. Hepatology 2007, 46(2):548-557.

11. Bystrykh L, Weersing E, Dontje B, Sutton S, Pletcher MT, Wiltshire T, Su Al,

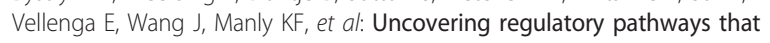
affect hematopoietic stem cell function using 'genetical genomics'. Nat Genet 2005, 37(3):225-232.

12. Bao L, Wei L, Peirce JL, Homayouni $R$, Li H, Zhou M, Chen H, Lu L, Williams RW, Pfeffer $L M$, et al: Combining gene expression QTL mapping and phenotypic spectrum analysis to uncover gene regulatory relationships. Mamm Genome 2006, 17(6):575-583.

13. Chesler EJ, Lu L, Wang J, Williams RW, Manly KF: WebQTL: rapid exploratory analysis of gene expression and genetic networks for brain and behavior. Nat Neurosci 2004, 7(5):485-486.

14. Irizarry RA, Hobbs B, Collin F, Beazer-Barclay YD, Antonellis KJ, Scherf U, Speed TP: Exploration, normalization, and summaries of high density oligonucleotide array probe level data. Biostatistics 2003, 4(2):249-264.

15. Haley CS, Knott SA: A simple regression method for mapping quantitative trait loci in line crosses using flanking markers. Heredity 1992, 69(4):315-324.

16. Shifman S, Bell JT, Copley RR, Taylor MS, Williams RW, Mott R, Flint J: A high-resolution single nucleotide polymorphism genetic map of the mouse genome. PLoS Biol 2006, 4(12):e395.

17. Williams RW, Gu J, Qi S, Lu L: The genetic structure of recombinant inbred mice: high-resolution consensus maps for complex trait analysis. Genome Biol 2001, 2(11):RESEARCH0046.

18. Brockdorff N, Ashworth A, Kay GF, Cooper P, Smith S, McCabe VM, Norris DP, Penny GD, Patel D, Rastan S: Conservation of position and exclusive expression of mouse Xist from the inactive $X$ chromosome. Nature 1991, 351(6324):329-331.

19. Wu C, Orozco C, Boyer J, Leglise M, Goodale J, Batalov S, Hodge CL, Haase J, Janes J, Huss JW, et al: BioGPS: an extensible and customizable portal for querying and organizing gene annotation resources. Genome Biol 2009, 10(11):R130.

20. Boon AC, deBeauchamp J, Hollmann A, Luke J, Kotb M, Rowe S, Finkelstein D, Neale G, Lu L, Williams RW, et al: Host genetic variation affects resistance to infection with a highly pathogenic $\mathrm{H} 5 \mathrm{~N} 1$ influenza A virus in mice. J Virol 2009, 83(20):10417-10426. 
21. Cartner SC, Simecka JW, Briles DE, Cassell GH, Lindsey JR: Resistance to mycoplasmal lung disease in mice is a complex genetic trait. Infect Immun 1996, 64(12):5326-5331.

22. Hiraoka N, Kawashima H, Petryniak B, Nakayama J, Mitoma J, Marth JD, Lowe JB, Fukuda M: Core 2 branching beta1,6-Nacetylglucosaminyltransferase and high endothelial venule-restricted sulfotransferase collaboratively control lymphocyte homing. J Biol Chem 2004, 279(4):3058-3067.

23. Cao S, Liu J, Chesi M, Bergsagel PL, Ho IC, Donnelly RP, Ma X: Differential regulation of IL-12 and IL-10 gene expression in macrophages by the basic leucine zipper transcription factor c-Maf fibrosarcoma. J Immunol 2002, 169(10):5715-5725.

24. Cao S, Liu J, Song L, Ma X: The protooncogene c-Maf is an essential transcription factor for IL-10 gene expression in macrophages. J Immunol 2005, 174(6):3484-3492.

25. Hiramatsu Y, Suto A, Kashiwakuma D, Kanari H, Kagami S, Ikeda K, Hirose K, Watanabe N, Grusby MJ, Iwamoto I, et al: c-Maf activates the promoter and enhancer of the IL-21 gene, and TGF-beta inhibits c-Maf-induced IL21 production in CD4+ T cells. J Leukoc Biol 2010, 87(4):703-712.

26. Nakamura M, Hamada M, Hasegawa K, Kusakabe M, Suzuki H, Greaves DR, Moriguchi T, Kudo T, Takahashi S: c-Maf is essential for the F4/80 expression in macrophages in vivo. Gene 2009, 445(1-2):66-72.

27. Pot $C$, Jin H, Awasthi A, Liu SM, Lai CY, Madan R, Sharpe AH, Karp CL, Miaw SC, Ho IC, et al: Cutting edge: IL-27 induces the transcription factor c-Maf, cytokine IL-21, and the costimulatory recep-tor ICOS that coordinately act together to promote differentiation of IL-10-producing Tr1 cells. J Immunol 2009, 183(2):797-801.

28. Voice J, Donnelly S, Dorsam G, Dolganov G, Paul S, Goetzl EJ: c-Maf and JunB mediation of Th2 differentiation induced by the type $2 \mathrm{G}$ proteincoupled receptor (VPAC2) for vasoactive intestinal peptide. J Immunol 2004, 172(12):7289-7296.

29. Xu J, Yang Y, Qiu G, Lal G, Wu Z, Levy DE, Ochando JC, Bromberg JS, Ding Y: c-Maf regulates IL-10 expression during Th17 polarization. $\mathrm{J}$ Immunol 2009, 182(10):6226-6236.

30. Tordjman R, Lepelletier $Y$, Lemarchandel V, Cambot M, Gaulard P, Hermine O, Romeo PH: A neuronal receptor, neuropilin-1, is essential for the initiation of the primary immune response. Nat Immunol 2002, 3(5):477-482.

31. Wulfing C, Rupp F: Neuropilin-1: another neuronal molecule in the "immunological synapse". Nat Immunol 2002, 3(5):418-419.

32. Bridges JP, Wert SE, Nogee LM, Weaver TE: Expression of a human surfactant protein $C$ mutation associated with interstitial lung disease disrupts lung development in transgenic mice. J Biol Chem 2003, 278(52):52739-52746.

33. Glasser SW, Detmer EA, Ikegami M, Na CL, Stahlman MT, Whitsett JA: Pneumonitis and emphysema in $\mathrm{sp}-\mathrm{C}$ gene targeted mice. J Biol Chem 2003, 278(16):14291-14298

34. Glasser SW, Witt TL, Senft AP, Baatz JE, Folger D, Maxfield MD, Akinbi HT, Newton DA, Prows DR, Korfhagen TR: Surfactant protein C-deficient mice are susceptible to respiratory syncytial virus infection. Am J Physiol Lung Cell Mol Physiol 2009, 297(1):L64-72.

35. Stripp BR, Reynolds SD, Boe IM, Lund J, Power JH, Coppens JT, Wong V, Reynolds PR, Plopper CG: Clara cell secretory protein deficiency alters clara cell secretory apparatus and the protein composition of airway lining fluid. Am J Respir Cell Mol Biol 2002, 27(2):170-178.

36. Porter D, Lahti-Domenici J, Torres-Arzayus M, Chin L, Polyak K: Expression of high in normal-1 (HIN-1) and uteroglobin related protein-1 (UGRP-1) in adult and developing tissues. Mech Dev 2002, 114(1-2):201-204.

37. Chiba Y, Kusakabe T, Kimura S: Decreased expression of uteroglobinrelated protein 1 in inflamed mouse airways is mediated by IL-9. Am J Physiol Lung Cell Mol Physiol 2004, 287(6):L1193-1198.

38. Kurotani R, Tomita T, Yang Q, Carlson BA, Chen C, Kimura S: Role of secretoglobin 3A2 in lung development. Am J Respir Crit Care Med 2008, 178(4):389-398.

39. Bohinski RJ, Huffman JA, Whitsett JA, Lattier DL: Cis-active elements controlling lung cell-specific expression of human pulmonary surfactant protein B gene. J Biol Chem 1993, 268(15):11160-11166.

40. Bein K, Wesselkamper SC, Liu X, Dietsch M, Majumder N, Concel VJ, Medvedovic M, Sartor MA, Henning LN, Venditto C, et al: Surfactantassociated protein $B$ is critical to survival in nickel-induced injury in mice. Am J Respir Cell Mol Biol 2009, 41(2):226-236.
41. Melton KR, Nesslein LL, Ikegami M, Tichelaar JW, Clark JC, Whitsett JA, Weaver TE: SP-B deficiency causes respiratory failure in adult mice. Am J Physiol Lung Cell Mol Physiol 2003, 285(3):L543-549.

42. LeClair EE, Nomellini V, Bahena M, Singleton V, Bingle L, Craven CJ, Bingle CD: Cloning and expression of a mouse member of the PLUNC protein family exclusively expressed in tongue epithe-lium. Genomics 2004, 83(4):658-666.

43. Bingle CD, Craven CJ: PLUNC: a novel family of candidate host defence proteins expressed in the upper airways and nasopharynx. Hum Mol Genet 2002, 11(8):937-943.

44. Chu HW, Thaikoottathil J, Rino JG, Zhang G, Wu Q, Moss T, Refaeli Y, Bowler R, Wenzel SE, Chen Z, et al: Function and regulation of SPLUNC1 protein in Mycoplasma infection and allergic inflam-mation. J Immunol 2007, 179(6):3995-4002.

45. Canon $A B$ : White sponge nevus of the mucosa (nevus spongiosus albus mucosa). Arch Dermatol Syphilol 1935, 31:365-370.

46. Terrinoni A, Rugg EL, Lane EB, Melino G, Felix DH, Munro CS, McLean WH: A novel mutation in the keratin 13 gene causing oral white sponge nevus. J Dent Res 2001, 80(3):919-923.

47. Rugg EL, McLean WH, Allison WE, Lunny DP, Macleod Rl, Felix DH, Lane EB, Munro CS: A mutation in the mucosal keratin $\mathrm{K} 4$ is associated with oral white sponge nevus. Nat Genet 1995, 11(4):450-452.

48. Trapani JA, Smyth MJ: Functional significance of the perforin/granzyme cell death pathway. Nat Rev Immunol 2002, 2(10):735-747.

49. Nebert DW, Dalton TP, Okey AB, Gonzalez FJ: Role of aryl hydrocarbon receptor-mediated induction of the CYP1 enzymes in environmental toxicity and cancer. J Biol Chem 2004, 279(23):23847-23850.

50. Okey $A B$, Riddick DS, Harper PA: The Ah receptor: mediator of the toxicity of 2,3,7,8-tetrachlorodibenzo-p-dioxin (TCDD) and related compounds. Toxicol Lett 1994, 70(1):1-22.

51. Sutter CH, Yin H, Li Y, Mammen JS, Bodreddigari S, Stevens G, Cole JA, Sutter TR: EGF receptor signaling blocks aryl hydrocarbon receptormediated transcription and cell differentiation in human epidermal keratinocytes. Proc Natl Acad Sci USA 2009, 106(11):4266-4271.

52. Denison MS, Fisher JM, Whitlock JP Jr: Protein-DNA interactions at recognition sites for the dioxin-Ah receptor complex. J Biol Chem 1989, 264(28):16478-16482.

53. Chang C, Smith DR, Prasad VS, Sidman CL, Nebert DW, Puga A: Ten nucleotide differences, five of which cause amino acid changes, are associated with the Ah receptor locus polymorphism of C57BL/6 and DBA/2 mice. Pharmacogenetics 1993, 3(6):312-321.

\section{doi:10.1186/1465-9921-12-61}

Cite this article as: Alberts et al:: Genome-wide analysis of the mouse lung transcriptome reveals novel molecular gene interaction networks and cell-specific expression signatures. Respiratory Research 2011 12:61.

\section{Submit your next manuscript to BioMed Central and take full advantage of:}

- Convenient online submission

- Thorough peer review

- No space constraints or color figure charges

- Immediate publication on acceptance

- Inclusion in PubMed, CAS, Scopus and Google Scholar

- Research which is freely available for redistribution 